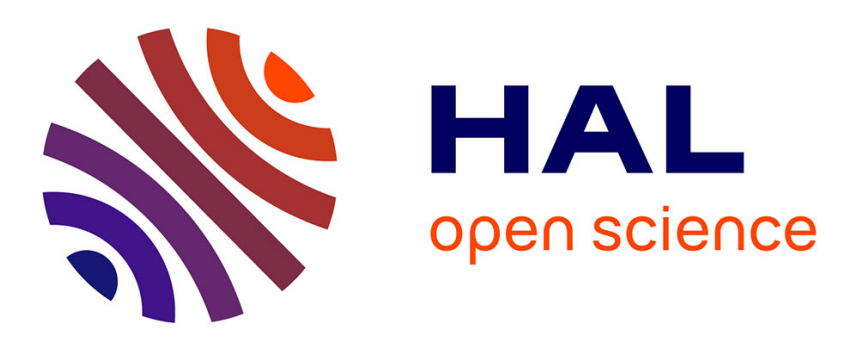

\title{
Detection of superoxide production in stimulated and unstimulated living cells using new cyclic nitrone spin traps
}

Kahina Abbas, Micael Hardy, Florent Poulhès, Hakim Karoui, Paul Tordo, Olivier Ouari, Fabienne Peyrot

\section{To cite this version:}

Kahina Abbas, Micael Hardy, Florent Poulhès, Hakim Karoui, Paul Tordo, et al.. Detection of superoxide production in stimulated and unstimulated living cells using new cyclic nitrone spin traps. Free Radical Biology and Medicine, 2014, 71, pp.281 - 290. 10.1016/j.freeradbiomed.2014.03.019 . hal-01414138

\author{
HAL Id: hal-01414138 \\ https://hal.science/hal-01414138
}

Submitted on 20 May 2020

HAL is a multi-disciplinary open access archive for the deposit and dissemination of scientific research documents, whether they are published or not. The documents may come from teaching and research institutions in France or abroad, or from public or private research centers.
L'archive ouverte pluridisciplinaire HAL, est destinée au dépôt et à la diffusion de documents scientifiques de niveau recherche, publiés ou non, émanant des établissements d'enseignement et de recherche français ou étrangers, des laboratoires publics ou privés. 
Free Radical Biology \& Medicine Accepted manuscript

Published in final edited form as:

Free Radic Biol Med. 2014 Jun; 71: 281-90. doi: 10.1016/j.freeradbiomed.2014.03.019

Detection of superoxide production in stimulated and non stimulated living cells using new cyclic nitrone spin traps

\title{
Kahina Abbas ${ }^{\mathrm{a}}$, Micael Hardy ${ }^{\mathrm{b}}$, Florent Poulhès ${ }^{\mathrm{b}}$, Hakim Karoui ${ }^{\mathrm{b}}$, Paul Tordo ${ }^{\mathrm{b}}$, Olivier Ouari $^{\mathrm{b}}$, and Fabienne Peyrot ${ }^{\mathrm{a}, \mathrm{c}^{*}}$
}

${ }^{\text {a }}$ Laboratoire de Chimie et Biochimie Pharmacologiques et Toxicologiques (UMR CNRS 8601), Université Paris Descartes, Sorbonne Paris Cité, 45 rue des Saints-Pères, 75006 Paris, France.

b Aix-Marseille Université, CNRS, ICR UMR 7273, 13397 Marseille cedex 20, France

c ESPE de l'académie de Paris, Université Paris Sorbonne, 10 rue Molitor, 75016 Paris, France.

* Corresponding author: Fabienne Peyrot

45 rue des Saints-Pères

75006 Paris, France

Tel : 33 (0)1 42862175

E-mail : fabienne.peyrot@parisdescartes.fr

Running title: Cellular superoxide detection with new spin traps

Keywords: Cyclic nitrones, ESR spectroscopy, EPR spectroscopy, Spin-trapping, Superoxide, Hydroxyl radical, RAW macrophages, Free radical.

\begin{abstract}
Reactive oxygen species (ROS) including superoxide anion and hydrogen peroxide $\left(\mathrm{H}_{2} \mathrm{O}_{2}\right)$ have a diverse array of physiological and pathological effects within living cells depending on the extent, timing, and location of their production. For measuring ROS production in cells, the ESR spin trapping technique using cyclic nitrones distinguishes itself from other methods by its specificity for superoxide and hydroxyl radical. However, several drawbacks, such as the low spin trapping rate and the spontaneous and cell-enhanced decomposition of the spin adducts to ESR-silent products, limit the application of this method to biological systems.

Recently, new cyclic nitrones bearing a triphenylphosphonium (Mito-DIPPMPO) or a permethylated $\beta$-cyclodextrin moiety (CD-DIPPMPO) have been synthesized and their spin adducts demonstrated increased stability in buffer. In this study, a comparison of the spin trapping efficiency of these new compounds with commonly used cyclic nitrone spin traps, i.e. 5,5-dimethyl-1-pyrroline $N$-oxide (DMPO), and analogues BMPO, DEPMPO, and DIPPMPO, was performed on RAW 264.7 macrophages stimulated with phorbol 12-myristate 13-acetate (PMA).

Our results show that Mito-DIPPMPO and CD-DIPPMPO enable a higher detection of superoxide adduct, with a low (if any) amount of hydroxyl adduct. CD-DIPPMPO, especially, appears as a superior spin trap for extracellular superoxide detection in living macrophages, allowing measurement of a superoxide production in non stimulated cells for the first time. The main rationale put forward for this extreme sensitivity is that the extracellular localization of the spin trap prevents the reduction of the spin adducts by ascorbic acid and glutathione within cells.
\end{abstract}




\section{Introduction}

ROS, including superoxide radical $\left(\mathrm{O}_{2}^{--}\right)$and its disproportionation product $\mathrm{H}_{2} \mathrm{O}_{2}$, are byproducts of normal aerobic metabolism of the cell. Under physiological conditions, their concentration is kept finely under control by antioxidant enzymes, such as superoxide dismutase (SOD) or catalase. This basal level is involved in cell signaling and regulation of physiological processes such as differentiation, proliferation, and apoptosis ${ }^{[1,2]}$. Inflammatory response to pathogens also relies on the production of $\mathrm{O}_{2}, \mathrm{H}_{2} \mathrm{O}_{2}$, $\mathrm{NO}$ and hypochlorous acid $(\mathrm{HOCl})$ by macrophages and neutrophils, leading to bacterial killing. However, excessive production or a failure in antioxidant defenses results in the accumulation of oxidative damage to cell constituents (proteins, DNA, carbohydrates, and lipids). These events of oxidative stress have been witnessed at the onset and evolution of many diseases, including cancer, cardiovascular pathologies, and neurological disorders ${ }^{[3-5]}$.

Sensitive and specific detection of ROS, and especially of $\mathrm{O}_{2}{ }^{-}$as a parent species for other ROS, is an on-going focus in biomedical research. Spin trapping of superoxide with cyclic nitrones coupled to ESR detection was introduced in the $1970 \mathrm{~s}^{[6]}$. The principle of this method relies on the reaction of the short-lived radical of interest with a diamagnetic molecule, the spin trap, to form a persistent aminoxyl (nitroxide) radical, called the spin adduct. Ideally, the ESR spectrum of the adduct is characteristic of the initially trapped radical, which confers its high specificity to this method over other techniques based on fluorescent and chemiluminescent probes or on hydroxylamine spin probes ${ }^{[7]}$.

DMPO (Scheme 1) was the first cyclic nitrone spin trap successfully used for detecting ROS on chloroplasts ${ }^{[8]}$ and then on intact cells, i.e. stimulated neutrophils and macrophages in the late 1970 s and early $1980 \mathrm{~s}^{[9-12]}$. However, severe limitations occur with DMPO: the low spin trapping rate, which makes high spin trap concentrations (50-100 $\mathrm{mM}$ ) mandatory to compete with superoxide disproportionation, and the short half-life of the superoxide adduct (DMPO$\mathrm{OOH}$, less than $1 \mathrm{~min}$ at physiological $\mathrm{pH}$ ), whose decomposition is accompanied by the formation of the hydroxyl adduct (DMPO-OH). Moreover, metabolic processes in biological systems further reduce the stability of the adducts and enhance the conversion of superoxide to hydroxyl adducts ${ }^{[13]}$. Control experiments with SOD are required to distinguish between superoxide and hydroxyl radical trapping.

Electron withdrawing groups at position 5, as in DEPMPO (5-diethoxyphosphoryl-5-methyl1-pyrroline $N$-oxide) ${ }^{[14]}$, DIPPMPO (5-diisopropoxyphosphoryl-5-methyl-1-pyrroline $\mathrm{N}$ oxide) ${ }^{[15]}$, BMPO (5-tert-butoxycarbonyl-5-methyl-1-pyrroline $N$-oxide) ${ }^{[16]}$, or EMPO (5ethoxycarbonyl-5-methyl-1-pyrroline $N$-oxide) ${ }^{[17]}$ (Scheme 1), were shown to improve the stability of the spin adducts in buffer. Several DEPMPO derivatives bearing a triphenylphosphonium group (Mito-DEPMPO ${ }^{[18,19]}$ and Mito-DIPPMPO) or a permethylated $\beta$-cyclodextrin moiety (CD-DEPMPO ${ }^{[20]}$ and CD-DIPPMPO, Scheme 1) were also synthesized and their superoxide adducts were shown to be very persistent. The half-lifetime values of the spin adducts depend significantly on the experimental conditions used, and thus the reported values may vary. Recently, in phosphate buffer at pH 7.4, we estimated the halflives of the superoxide adducts of Mito-DEPMPO, Mito-DIPPMPO, CD-DEPMPO, and CDDIPPMPO at $50 \pm 4,65 \pm 10,83 \pm 8$, and $109 \pm 10 \mathrm{~min}$, respectively, compared to $38 \pm 3 \mathrm{~min}$ for DEPMPO $^{[21]}$. Some selectivity of superoxide versus hydroxyl radical trapping was observed in vitro when the cyclic nitrone was substituted by a triphenylphosphonium group or a permethylated $\beta$-cyclodextrin moiety ${ }^{[21]}$. 
In previous studies ${ }^{[21,22]}$, we analyzed the resistance of superoxide adducts to decomposition processes involving microsomal and cytosolic enzymes responsible for the metabolism of xenobiotics. We emphasized the major roles of heme and hemeproteins, together with those of biological reductants such as ascorbic acid and glutathione, in the conversion of the superoxide and hydroxyl adducts of all cyclic nitrones to ESR silent compounds. By contrast, only CD-substituted spin traps appeared highly stable in the presence of microsomal proteins, being prevented to enter cytochrome P450 (P450) active site by steric constraints.

Here we evaluated the spin trapping efficiency of the two new cyclic nitrones, MitoDIPPMPO and CD-DIPPMPO, in comparison to four established spin traps (DMPO, BMPO, DEPMPO, and DIPPMPO) in the context of superoxide production by RAW macrophages. Treatment of RAW macrophages with PMA induces the activation of protein kinase $C$ that performs the phosphorylation of a critical residue in NADPH oxidase (NOX2) in the macrophage membrane ${ }^{[23]}$. This enzyme produces superoxide as part of the normal inflammatory process.

Moreover, we investigated the possibility of detecting superoxide production in unstimulated cells with these new spin traps - a challenging objective since many articles describe spin trapping results on stimulated cells ${ }^{[9-12,24-28]}$ but no production has ever been measured in non stimulated cells with cyclic nitrone spin traps using continuous wave ESR. Only rapid-scan ESR recently enabled detection with BMPO of superoxide produced by unstimulated Enterococcus faecalis ${ }^{[29]}$. We also analyzed the causes of the enhanced stability of the corresponding superoxide adducts in the presence of cells.

\section{Experimental procedures}

\section{Reagents}

BMPO and DIPPMPO were synthesized according to previously published protocols ${ }^{[15,16]}$. 2Diethoxyphosphoryl-2,5,5-trimethyl-pyrrolidin-1-oxyl (TOMER) was synthesized according to Le Moigne et al. ${ }^{[30]}$. Purity was determined by NMR and HPLC coupled with mass spectrometry and was above 98\%. Mito-DIPPMPO and CD-DIPPMPO were prepared using the procedures described for diethoxyphosphoryl analogues ${ }^{[18-20]}$. Their NMR and ESI-HRMS characterizations were previously published $^{[21]}$. DEPMPO was obtained from Radical Vision (Marseille, France). Tris(ethylenediamine)nickel(II) chloride 2-hydrate (Ni(en) ${ }_{3}{ }^{2+}$ ) was prepared according to M. Vanduijn et al. ${ }^{[31]}$. Diethylene triamine pentaacetic acid (DTPA), xanthine (X), xanthine oxidase (XO), catalase (CAT), catalase conjugated with polyethylene glycol (CAT-PEG), superoxide dismutase, superoxide dismutase conjugated with polyethylene glycol (SOD-PEG), (2,2,6,6-tetramethyl)piperidine-1-oxyl (TEMPO), 4-hydroxy-2,2,6,6tetramethylpiperidin-1-oxyl (TEMPOL), diphenyliodonium chloride (DPI), $\mathrm{N}, \mathrm{N}$ diethylaminoethyl 2,2-diphenylvalerate hydrochloride (SKF 525A), N-ethylmaleimide (NEM), phosphate-buffered saline (PBS, pH 7.1-7.5) were purchased from Sigma-Aldrich (Saint Quentin Fallavier, France).

\section{Culture of RAW macrophages}

Macrophages (RAW 264.7 cells), originally purchased from American Type Culture Collection (ATCC, CRL-9609'M), were a kind gift from Dr Jean-Claude Drapier (CNRS UPR 2301, Gif-sur-Yvette, France). Cells were cultured in Dulbecco's Modified Eagle Medium 
(DMEM AQmedia, Sigma-Aldrich) supplemented with 5\% fetal bovine serum (Lonza, Levallois-Perret, France) and 1\% penicillin/streptomycin (Invitrogen) in a water-jacketed incubator under $5 \% \mathrm{CO}_{2}$ at $37^{\circ} \mathrm{C}$.

Cell densities were determined by counting an appropriately diluted sample on a hemocytometer in the presence of trypan blue.

Ascorbic acid concentration in RAW macrophages was determined in the supernatant of freeze-thaw cell lysates by a previously described method ${ }^{[32]}$.

\section{Effect of the spin traps on cell viabilities}

Cell viability (trypan blue exclusion assay) in the presence of the spin traps was monitored under the conditions of study (5-10 mM spin trap, 20 min incubation in PBS buffer containing $1 \mathrm{mM}$ DTPA at $21^{\circ} \mathrm{C}$ ).

Longer-term incubations (6 h) in DMEM were also performed to assess the cell integrity in the presence of the spin traps ${ }^{[33]}$.

\section{Spin trapping of superoxide radical produced by X/XO system}

Determination of XO activity was performed by quantification of superoxide generation measured using the initial rates of reduction of ferric to ferrous cytochrome c. Cuvettes (total volume $150 \mu \mathrm{L}$ ) contained PBS, $1 \mathrm{mM}$ DTPA, $250 \mu \mathrm{M} \mathrm{X}, 100 \mathrm{U} / \mathrm{mL}$ CAT, $50 \mu \mathrm{M}$ cytochrome c, and variable amounts of XO. Spectra were recorded on a Uvikon 942 spectrophotometer (Kontron, Biotech) at $21^{\circ} \mathrm{C}$ and a $\Delta \varepsilon 550 \mathrm{~nm}$ value of $21,000 \mathrm{M}^{-1} \mathrm{~cm}^{-1}$ was used.

Ten millimolar spin traps were incubated with $250 \mu \mathrm{M} \mathrm{X}, \mathrm{XO}$, and $100 \mathrm{U} / \mathrm{mL}$ CAT, in PBS containing $1 \mathrm{mM}$ DTPA. The amount of XO was adjusted to release $2.8 \pm 0.3 \mu \mathrm{M} \mathrm{min}{ }^{-1}$ at $21^{\circ} \mathrm{C}$, as measured by the cytochrome $\mathrm{c}$ reduction assay. The reaction mixture was immediately transferred by aspiration into gas-permeable PTFE tubing (Extruded Sub-LiteWall@, inside diameter: $0.635 \mathrm{~mm}$, wall thickness: $0.051 \mathrm{~mm}$, Zeus Industrial Products Ltd., Ireland). The tubing was folded twice in a W-shape and inserted into a 4-mm ESR quartz tube for ESR analysis.

CD-DIPPMPO is subject to aggregation at $20 \mathrm{mM}$ as observed by DOSY NMR experiments (results not shown), which reduces the spin trapping rate. The rate of formation of the corresponding spin adduct was not significantly different between incubations containing 5 or $10 \mathrm{mM}$ CD-DIPPMPO. As a result, we used only $5 \mathrm{mM}$ for this spin trap.

\section{Spin trapping of superoxide radical produced by macrophages}

When indicated, confluent cells were stimulated with $5 \mu \mathrm{M}$ of PMA (Sigma-Aldrich) for 20 min in the dark at $37^{\circ} \mathrm{C}$. Cells were then washed twice with PBS and incubated for 5 min with Trypsine/EDTA (Sigma-Aldrich) at $37^{\circ} \mathrm{C}$. Harvested cells were centrifuged for $5 \mathrm{~min}$ at 190 $\mathrm{g}$, washed with PBS and centrifuged again.

RAW macrophages $\left(1-5 \times 10^{6}\right.$ cells $\left./ 100 \mu \mathrm{L}\right)$ were incubated with the indicated spin trap in PBS containing $1 \mathrm{mM}$ DTPA, with or without $200 \mathrm{U} / \mathrm{mL}$ SOD-PEG, and then transferred by aspiration into gas-permeable PTFE tubing. The tubing was folded twice into a W-shape and inserted into a 4-mm ESR quartz tube for ESR analysis. It is noteworthy that the start of the ESR measurements took place 2-5 minutes after the start of the incubation of the spin trap with RAW macrophages. This amount of time was required to gently re-suspend the cells in the solution, to fill and fold the gas-permeable tubing, to place it in the ESR cavity, and to 
tune the spectrometer.

In contrast to neutrophils that die soon after activation, macrophages are relatively long-lived cells $^{[34]}$. No significant increase in cell death was observed following activation with PMA during the time of the experiments.

Intra- versus extracellular localization of organic radical using $\mathrm{Ni}(\mathrm{en})_{3}{ }^{2+[35]}$

The cell-permeable TEMPOL and the cell-impermeable spin probe $\mathrm{Ni}(\mathrm{en}) 3^{2+}$ (final concentrations of $500 \mu \mathrm{M}$ and $100 \mathrm{mM}$, respectively) were added to a suspension of RAW macrophages $\left(3.6 \pm 0.3 \times 10^{6}\right.$ cells in $100 \mu \mathrm{L}$ PBS containing $1 \mathrm{mM}$ DTPA) and the reaction mixture was transferred into gas-permeable teflon tubing for ESR analysis.

CD-DIPPMPO ( $5 \mathrm{mM})$ was incubated for $20 \mathrm{~min}$ at $21^{\circ} \mathrm{C}$ in PBS, $\mathrm{pH} 7.4$, containing $\mathrm{X}$ (250 $\mu \mathrm{M}), \mathrm{XO}(8 \mathrm{mU} / \mathrm{mL})$, CAT $(100 \mathrm{U} / \mathrm{mL})$, and DTPA $(1 \mathrm{mM})$, followed by SOD addition (100 $\mathrm{U} / \mathrm{mL})$. When indicated, $\mathrm{Ni}(\mathrm{en}) 3^{2+}(100 \mathrm{mM})$ was then added and the mixture $(100 \mu \mathrm{L})$ was transferred into gas-permeable teflon tubing for ESR analysis. The same experiment was repeated in the presence of RAW cells $\left(3.6 \pm 0.3 \times 10^{6}\right.$ cells for $\left.100 \mu \mathrm{L}\right)$.

\section{Stability experiments}

The indicated spin traps $(5$ or $10 \mathrm{mM})$ were incubated for $20 \mathrm{~min}$ at $21^{\circ} \mathrm{C}$ in the presence of $\mathrm{X}$ $(250 \mu \mathrm{M}), \mathrm{XO}(8 \mathrm{mU} / \mathrm{mL}), \mathrm{CAT}(100 \mathrm{U} / \mathrm{mL})$ in PBS containing $1 \mathrm{mM}$ DTPA (final volume $100 \mu \mathrm{L})$. The reaction was stopped by SOD addition $(100 \mathrm{U} / \mathrm{mL})$. RAW macrophages $(0.5-$ $5 \times 10^{6}$ cells $/ 100 \mu \mathrm{L}$ ) or an equivalent volume of buffer were added to the solution containing superoxide adducts, and then transferred into gas-permeable teflon tubing for ESR analysis. When indicated, RAW macrophages were incubated with specific inhibitors or reagents prior to addition to the spin adduct under study.

\section{ESR spectroscopy}

ESR measurements were performed using a Bruker Elexsys 500 ESR spectrometer (Bruker, Wissembourg, France), operating at X-band $(9.85 \mathrm{GHz})$ and equipped with a SHQ highsensitivity cavity. Typical settings used were: microwave power, $10 \mathrm{~mW}$; modulation frequency, $100 \mathrm{kHz}$; modulation amplitude, $0.2 \mathrm{mT}$; receiver gain, $60 \mathrm{~dB}$; time constant, 40.96 ms; conversion time, $41.04 \mathrm{~ms}$; datapoints, 1024; sweep width, $15 \mathrm{mT}$; sweep time, $42.02 \mathrm{~s}$. ESR spectra were recorded sequentially during the whole reaction course at $21^{\circ} \mathrm{C}$. Data acquisition and processing were performed using Bruker Xepr software. Calibration of the spectrometer sensitivity was deduced from the accurate computer simulation of spectra of TEMPO or TOMER solutions of known concentrations.

\section{Noise filtration using the singular value decomposition method (SVD) method}

When indicated, the noise in the ESR spectra was filtered using the SVD method described by Lauricella et al. ${ }^{[36]}$.

\section{Computer simulations}

Computer simulations of the ESR spectra were performed using the program of Rockenbauer and Korecz ${ }^{[37]}$. In addition to the g-factor and hyperfine coupling constants, the relaxation and 
Free Radical Biology \& Medicine Accepted manuscript

Published in final edited form as:

Free Radic Biol Med. 2014 Jun; 71: 281-90. doi: 10.1016/j.freeradbiomed.2014.03.019

exchange parameters were optimized from the best resolved spectra, and when necessary, two or three superimposed components were taken into account. Normalized line shapes were used, giving concentration data for all components.

\section{Results}

Spin trapping of superoxide radical produced by the $X / X O$ system

In a first experiment, we incubated six spin traps with $\mathrm{X}$ and $\mathrm{XO}$, that produced a constant flux of superoxide radical $\left(2.8 \pm 0.3 \mu \mathrm{M} \mathrm{min}{ }^{-1}\right)$, and monitored the accumulation of the corresponding superoxide adducts in PBS at $21^{\circ} \mathrm{C}$ (Fig. 1). DTPA $(1 \mathrm{mM})$ was used to prevent catalysis of the Fenton reaction by trace metal ions. No hydroxyl adduct was detected in these experiments. In the presence of $10 \mathrm{mM}$ DMPO, the signal of DMPO-OOH $\left(\mathrm{A}_{\mathrm{N}}=1.41 \mathrm{mT}\right.$, $\mathrm{A}_{\mathrm{H} \beta}=1.15 \mathrm{mT}, \mathrm{A}_{\mathrm{H} \gamma}=0.11 \mathrm{mT}$ ) corresponding to a steady-state concentration around $1 \mu \mathrm{M}$ was observed. On the contrary, the superoxide adducts of BMPO, DEPMPO, DIPPMPO, and Mito-DIPPMPO (all nitrones used at $10 \mathrm{mM}$ ) accumulated with time at an initial rate of 0.8 $1.2 \pm 0.2 \mu \mathrm{M} \mathrm{min}{ }^{-1}$ that slowly decreased, except for Mito-DIPPMPO. With $5 \mathrm{mM} \mathrm{CD}$ DIPPMPO, the increase in concentration of CD-DIPPMPO-OOH was higher and perfectly linear $\left(1.5 \pm 0.2 \mu \mathrm{M} \mathrm{min}{ }^{-1}\right)$.

\section{Spin trapping in PMA-stimulated RAW macrophages}

No decrease in cell viability (defined as the percentage of cells that excluded the trypan blue, Mean $\pm S D, n=4$ ) was observed after exposure to spin traps in the medium for $6 \mathrm{~h}$ : control

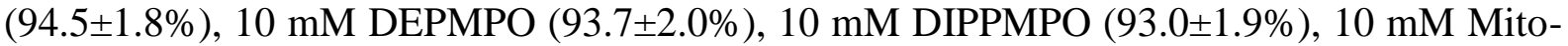
DIPPMPO (93.0 $\pm 1.9 \%)$, or $5 \mathrm{mM}$ CD-DIPPMPO (94.2 $\pm 1.5 \%)$. Also no change in the number of viable cells was found between the control and cells incubated under the conditions of the study (20 min, 5-10 mM spin traps and $1 \mathrm{mM}$ DTPA in PBS). We thus compared the ability of the spin traps to detect superoxide produced by RAW macrophages stimulated by PMA.

Incubations were performed using living cell suspensions in PBS containing $1 \mathrm{mM}$ DTPA, because culture medium components have been described to interfere with spin trapping ${ }^{[38]}$. High concentrations of DEPMPO (up to $50 \mathrm{mM}$ ) provided strong signal-to-noise ratios in the ESR spectra, while the signal could still be detected with $0.5 \mathrm{mM}$ spin trap, provided the number of accumulated scans was large. The concentration of $10 \mathrm{mM}$ spin trap allowed us to obtain a clear ESR detection with DEPMPO within a few minutes, by optimization of the ESR acquisition parameters (Fig. 2). We thus chose this concentration for all spin traps, except for CD-DIPPMPO $(5 \mathrm{mM})$. Indeed $10 \mathrm{mM}$ CD-DIPPMPO yielded a slightly lower detection in the presence of PMA-stimulated RAW macrophages.

Representative ESR spectra obtained in these experiments are presented in Fig. 2. In some cases, they resulted from overlapping signals of superoxide and hydroxyl radical adducts. Computer simulation was required to separate the contributions of each adducts. For this purpose, we used the program of Rockenbauer and Korecz ${ }^{[37]}$ using hyperfine coupling constants $\left(A_{P}, A_{N}, A_{H \beta}\right)$ and simulation parameters described in a previous work ${ }^{[21]}$ and detailed in the supplementary information (Supplementary Fig. S1 and Table S1). With DMPO, BMPO, and DIPPMPO, the ESR spectra were only due to the hydroxyl radical adducts (Fig. 3). DEPMPO and Mito-DIPPMPO gave a mixture of superoxide and hydroxyl adducts with opposite ratios (20\% and $75 \%$ of superoxide adduct with DEPMPO and MitoDIPPMPO, respectively). On the contrary, only the superoxide adduct was observed in the 
case of CD-DIPPMPO. We cannot exclude, however, that traces of hydroxyl radical adduct could be concealed by the high intensity and large line-width of the spectrum of CDDIPPMPO-OOH, especially since traces of hydroxyl adduct were detected when SOD-PEG was added to the incubation, preventing the build-up of the superoxide adduct.

Typical evolution with time of the concentration of superoxide and hydroxyl radical adducts during the spin trapping reaction in cells is presented in Figures $4 \mathrm{~A}$ and $4 \mathrm{~B}$, respectively. Using $3.6 \pm 0.3 \times 10^{6}$ cells in $100 \mu \mathrm{L}$, the concentration of DEPMPO-OOH increased up to 7 min after the start of ESR recording, reached a maximum of $1.0 \pm 0.7 \mu \mathrm{M}$, and then slowly decreased, while the concentration of DEPMPO-OH increased steadily throughout the experiment, reaching a plateau after $25 \mathrm{~min}$. The superoxide adduct of DIPPMPO was hardly detected at the start of the ESR monitoring and decayed from then on. DIPPMPO-OH

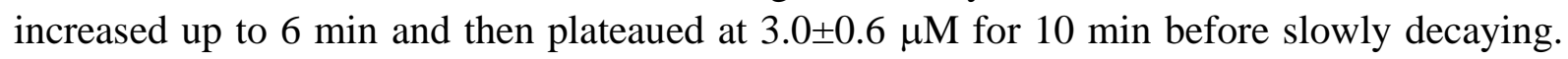
The behavior of Mito-DIPPMPO was similar to that of DEPMPO but the increase in superoxide adduct was sustained slightly longer, yielding a higher maximum $(\approx 2.2 \pm 0.5 \mu \mathrm{M})$, and then its decay was slower. In parallel, Mito-DIPPMPO-OH increased almost linearly throughout the experiment at a slower rate than DEPMPO-OH. For CD-DIPPMPO, the rate of formation of the superoxide adduct was very high from the start $\left(1.2 \pm 0.3 \mu \mathrm{M} \cdot \mathrm{min}^{-1}\right)$ and slowly decreased after $7 \mathrm{~min}$, probably following cell sedimentation that reduced oxygen availability. The concentration of CD-DIPPMPO-OOH reached a plateau at $20 \pm 2 \mu \mathrm{M}$, which is 9 times more than the maximum of superoxide adduct obtained with the other spin traps. The rate of CD-DIPPMPO-OOH formation increased linearly when cell number increased for the cell densities from 1 to $5 \times 10^{6}$ cells $/ 100 \mu \mathrm{L}$ (data not shown).

\section{Origin of the signal: superoxide versus hydroxyl radical}

Incubation in the presence of SOD-PEG, a membrane permeable superoxide dismutase, completely prevented the formation of superoxide adducts, while it markedly decreased the level of hydroxyl radical adducts (Fig. 3). This indicates that hydroxyl radical is not the major pathway for the formation of hydroxyl radical adducts and that they arise mainly from reduction of the corresponding superoxide adducts or possibly that the superoxide radical is the source of the hydroxyl radical. The fact that the formation of hydroxyl radical adducts was not completely prevented by action of SOD-PEG could either be due to trace formation of hydroxyl radical, or to an incomplete trapping of superoxide inside the cell, since SOD-PEG incorporation in the cell is a slow process ${ }^{[39]}$.

Addition of CAT-PEG did not decrease the amount of superoxide adduct, showing that nucleophilic addition of $\mathrm{H}_{2} \mathrm{O}_{2}$ followed by one-electron oxidation to the aminoxyl radical (Forrester-Hepburn mechanism $^{[40]}$ ) did not occur in these experiments.

\section{Detection of superoxide production in non stimulated RAW macrophages}

In the absence of PMA-induced stimulation, no spin trapping of superoxide occurred with either DMPO, BMPO, DEPMPO, DIPPMPO, or Mito-DIPPMPO (Fig. 2). On the contrary, superoxide detection in non stimulated cells could be performed with CD-DIPPMPO, even if the signal was rather low. This was made clearer after application of noise filtration by the SVD method to the spectrum (Fig. 5). No signal was detected with CD-DIPPMPO in cell-free incubations under the same conditions. 
Free Radical Biology \& Medicine Accepted manuscript

Published in final edited form as:

Free Radic Biol Med. 2014 Jun; 71: 281-90. doi: 10.1016/j.freeradbiomed.2014.03.019

Stability of the superoxide adducts of DEPMPO, Mito-DIPPMPO, and CD-DIPPMPO in the presence of macrophages

To understand the discrepancies in the behavior of spin traps in the presence of RAW macrophages, we monitored, under different conditions, the stability of superoxide adducts of DEPMPO, Mito-DIPPMPO and CD-DIPPMPO, prepared with the X/XO system. RAW macrophages $\left(3.6 \pm 0.3 \times 10^{6}\right.$ cells $\left./ 100 \mu \mathrm{L}\right)$ dramatically accelerated (16 fold) the decay of DEPMPO-OOH compared to buffer (Fig. 6A), while the formation of DEPMPO-OH was enhanced (Fig. 6B). The latter was in turn rapidly transformed to ESR-silent compounds. Part of these effects could be inhibited by incubation of the cells with NEM (300 $\mu \mathrm{M}, 10 \mathrm{~min}$ ), a thiol-blocking reagent (Fig. 6A and 6B). On the contrary, incubation of the cells with DPI (10$50 \mu \mathrm{M}, 30$-min pre-incubation), an inhibitor of flavoenzymes, or SKF 525A $(50 \mu \mathrm{M})$, an inhibitor of P450, had no effect (results not shown). The decay rate of DEPMPO-OOH increased dramatically as the cell number increased from 0.5 to $5 \times 10^{6}$ cells $/ 100 \mu \mathrm{L}$, while the rate of formation and decay of DEPMPO-OH were also enhanced (data not shown). RAW macrophages only caused a 4-fold acceleration in the decay of Mito-DIPPMPO-OOH and the conversion of Mito-DIPPMPO-OOH to the corresponding hydroxyl adduct was enhanced by cells. In contrast with these results, RAW macrophages induced a minor (2-fold) acceleration in the decay of CD-DIPPMPO-OOH (Fig. 7A) and this effect was independent of the cell number (from 1 to $5 \times 10^{6}$ cells $/ 100 \mu \mathrm{L}$ ) (data not shown). Though the conversion to CDDIPPMPO-OH was slightly enhanced, the latter appeared relatively stable in the presence of cells because its concentration increased quasi-linearly with time (Fig. 7B).

\section{Level of superoxide production}

The rate of formation of the superoxide adduct of CD-DIPPMPO in the presence of PMAstimulated RAW macrophages $\left(3.6 \pm 0.3 \times 10^{6}\right.$ cells in $\left.100 \mu \mathrm{L}\right)$ was approximately $1.2 \pm 0.3$ $\mu \mathrm{M} \cdot \mathrm{min}^{-1}$, comparable to that obtained previously with a superoxide flux of $2.8 \pm 0.3 \mu \mathrm{M} . \mathrm{min}^{-1}$ produced by the $\mathrm{X} / \mathrm{XO}$ system. The superoxide production in PMA-stimulated RAW macrophages was thus estimated around $80 \pm 10 \mathrm{pmol} / 10^{6}$ cells $/ \mathrm{min}$ in our experiments. In a similar manner, we estimated the superoxide production in non stimulated macrophages to $3 \pm 2 \mathrm{pmol} / 10^{6}$ cells $/ \mathrm{min}$. These values neglect the fact that the adduct is decomposed by the cells but this assumption is supported by the above-mentioned results.

\section{Intra- versus extracellular localization of the spin trapping reaction}

To further understand why CD-DIPPMPO appeared as a superior spin trap for superoxide under our conditions, we investigated its localization in cell suspensions. Paramagnetic metal ions interact with organic radicals via concentration- and distance-dependent magnetic relaxation enhancement mechanisms (Heisenberg exchange), leading to line-broadening and diminution of intensity of the ESR signal of the organic radical. Here we used the membraneimpermeable, redox inert complex tris(ethylenediamine)nickel(II) $\left(\mathrm{Ni}(\mathrm{en}) 3^{2+}\right)^{[35]}$ as a probe to distinguish between superoxide adduct inside and outside RAW macrophages. We first tested the ability of $\mathrm{Ni}(\mathrm{en}) 3^{2+}$ to cross the membrane of RAW macrophages in cell suspensions containing the membrane-permeable aminoxyl radical TEMPOL. After $\mathrm{Ni}(\mathrm{en})_{3}{ }^{2+}$ addition, the ESR spectrum showed the superimposition of the sharp intracellular TEMPOL spectrum and the broadened extracellular signal (Supplementary Fig. S3).

We then used CD-DIPPMPO-OOH, formed in the reaction with the $\mathrm{X} / \mathrm{XO}$ system, as a probe for the penetration of CD-DIPPMPO in the cell. In the presence of RAW macrophages, 
$\mathrm{Ni}(\mathrm{en}) 3^{2+}$ addition yielded line-broadening and reduced intensity of CD-DIPPMPO-OOH in the same manner as in the absence of cells, suggesting that the adduct does not cross the cell membrane in a significant manner (Fig. 8).

\section{Discussion}

Although DMPO was frequently used in spin trapping studies of radicals in biological systems since its first successes in the $1970 \mathrm{~s}^{[9-12]}$, it has several drawbacks regarding the trapping of superoxide. Many spin traps that react faster with superoxide or form more persistent adducts than DMPO have been synthesized, among which BMPO, DEPMPO, and DIPPMPO that have already proven valuable in the study of biological ROS generation ${ }^{[41-43]}$. More recently, two cyclic nitrones bearing either a triphenylphosphonium group (MitoDIPPMPO) or a permethylated $\beta$-cyclodextrin moiety (CD-DIPPMPO) demonstrated a very high stability of the corresponding superoxide adducts and a relative selectivity for superoxide versus hydroxyl radical adducts ${ }^{[21]}$. However, their spin trapping abilities in cell cultures was never evaluated.

Here, the spin trapping efficiency of the spin traps was initially compared in vitro using an enzymatic production system of superoxide. An efficient spin trap is characterized by both a large spin trapping rate and a high intrinsic stability of the superoxide adduct in the reaction medium. DMPO appeared inefficient, due to the short half-life of DMPO-OOH $(<1 \mathrm{~min})$, while its spin trapping rate is of the same magnitude as that of other cyclic nitrones ${ }^{[44]}$. The fact that artifactual DMPO-OH did not accumulate through the rapid decomposition of the superoxide adduct could have resulted from its depletion by the high flux of superoxide ${ }^{[45]}$. Only with CD-DIPPMPO and Mito-DIPPMPO was the accumulation of the ESR signal perfectly linear in time over 15 min (Fig. 1), suggesting that the spontaneous decomposition of the superoxide adduct was negligible compared to its formation. However, when comparing the rate of formation of the superoxide adduct with the flux of superoxide produced by the X/XO system, we could conclude that only $30-35 \%$ of the superoxide radical was converted to the aminoxyl radical in the case of $10 \mathrm{mM}$ Mito-DIPPMPO and only 40$45 \%$ using $5 \mathrm{mM}$ CD-DIPPMPO, respectively. The spontaneous disproportionation of superoxide $\left(\mathrm{k} \sim 2 \times 10^{5} \mathrm{M}^{-1} \mathrm{~s}^{-1}\right.$ at $\mathrm{pH} 7.4^{[46]}$ ) obviously competed with the "slow" spin trapping reaction $\left(\mathrm{k}^{2} 100 \mathrm{M}^{-1} \mathrm{~s}^{-1}\right)^{[44]}$. In the case of DMPO, BMPO, or DEPMPO, large concentrations of spin traps (25-100 $\mathrm{mM})$ are commonly used to compensate for the low second-order rate constant of the reaction with superoxide ${ }^{[4]}$. With CD-DIPPMPO, this strategy is not applicable because the spin trap tends to aggregate at high concentrations, leading to a reduction in the spin trapping rate.

Most cyclic nitrone spin traps are considered relatively nontoxic in cell cultures at commonly used concentrations, although BMPO demonstrated some toxicity on CHO cells and different cancer cell lines at $50 \mathrm{mM}^{[28,33,43,48]}$. High concentrations of spin trap could, however, have a non negligible effect on cell metabolism, as shown with DMPO on macrophages ${ }^{[49]}$. Toxicity issues have also been raised for in vivo applications of spin traps: $20 \mathrm{mM}$ DEPMPO (average whole-body concentration) induced death in less than $1 \mathrm{~h}$ in mice ${ }^{[42]}$, while DMPO appeared safe up to $13 \mathrm{mM}$ in rats ${ }^{[50]}$. It is therefore desirable to lower the spin trap concentrations in order to reduce potential unwanted effects. Under the spin trapping conditions of this study, Mito-DIPPMPO and CD-DIPPMPO did not alter the viability of RAW macrophages, monitored by the trypan blue exclusion assay. Obviously, CD-DIPPMPO did not significantly interact with the cell membrane lipids. This is consistent with the observation that the 
disruption of phospholipid membranes occurs only at concentrations above $15 \mathrm{mM}$ for randomly methylated $\beta$-cyclodextrin ${ }^{[51]}$.

In our study, spin trapping using CD-DIPPMPO appeared as the most quantitative measurement of the superoxide radical produced by RAW macrophages stimulated by PMA (Fig. 2 and 3). Only the superoxide adduct was formed and its concentration after 8 min was 9 times higher than for the next best spin trap, an extent that could not be anticipated from initial experiments with X/XO. The greater contrast was with DMPO and BMPO, for which the concentration of the spin traps $(10 \mathrm{mM})$ was insufficient to accumulate significant amounts of spin adducts in the cells. Only trace amounts of SOD-inhibitable hydroxyl adducts were detected in both cases (similar to what has been observed with neutrophils ${ }^{[52]}$ ). Detection with DIPPMPO was also characterized by exclusive detection of the hydroxyl adduct, the major part of which derived from the trapping of superoxide (70\% decrease upon SOD-PEG addition). With DEPMPO, the superoxide adduct represented only $20 \%$ of the detection, while $80 \%$ of the hydroxyl adduct formation was also SOD-inhibitable. Mito-DIPPMPO, the second best spin trap, could detect superoxide more accurately than DEPMPO, with $75 \%$ of superoxide adduct.

We estimated the production of superoxide by PMA-stimulated RAW macrophages to $80 \pm 10$ $\mathrm{pmol} / 10^{6}$ cells/min, based on the detection with CD-DIPPMPO. The latter appeared so sensitive to low fluxes of superoxide that even production by RAW macrophages was measured in the absence of stimulation (Fig. 5), around $3 \pm 2 \mathrm{pmol} / 10^{6} \mathrm{cells} / \mathrm{min}$. This is, to our knowledge, the first superoxide production detected using a cyclic nitrone spin trap in non stimulated RAW macrophages. We can compare these results with the detection performed on human lymphoblast cell lines using the cell-permeable spin probe $\mathrm{CMH}$ (1-hydroxy-3methoxycarbonyl-2,2,5,5-tetramethylpyrrolidine $)^{[27]}: 48.6 \pm 8.2 \mathrm{pmol}_{2}{ }^{-\pi} / 10^{6}$ cells $/ \mathrm{min}$ in PMA-stimulated cells versus $5.5 \pm 0.5 \mathrm{pmol} \mathrm{O}_{2}{ }^{-} / 10^{6}$ cells $/ \mathrm{min}$ in non stimulated cells. Although the cell lines and conditions of experiment are different, it appears that CDDIPPMPO compares in sensitivity with hydroxylamine spin probes, while being far more specific for superoxide ${ }^{[7]}$.

How can we explain this superior ability of CD-DIPPMPO to detect superoxide in RAW macrophages, compared to other spin traps such as DEPMPO? This is a consequence of a slightly higher spin trapping rate and a higher intrinsic stability of the superoxide adduct, but not only that. First we see that CD-DIPPMPO-OOH is much more stable in the presence of cells (Fig. 7), than DEPMPO-OOH (Fig. 6). In a previous study using microsomal and cytosolic cell fractions, we identified heme and hemeproteins, reductases, and biological reductants such as ascorbic acid and glutathione, as major role players in the conversion of spin adducts to ESR-silent compounds ${ }^{[21,22]}$. Here, DEPMPO-OOH decayed mainly via reduction to DEPMPO-OH by thiols (a process inhibited by NEM, a thiol-blocking reagent), and via reduction to ESR-silent products by ascorbate (RAW macrophages contain about $120 \pm 10 \mu \mathrm{M}$ ascorbate in our hands). The contribution of P450 heme or flavin-dependent reductases to the decay of DEPMPO spin adducts in whole cells was ruled out using specific inhibitors (SKF 525A and DPI, respectively).

Not surprisingly, the superoxide adduct of Mito-DIPPMPO, which is substituted by a large lipophilic cation and designed to target mitochondria inside the cells, appeared very sensitive to cell-induced decomposition to ESR silent compounds in a similar way to that of DEPMPO, which is known to passively cross cell membranes ${ }^{[53]}$.

The processes responsible for the decay of CD-DIPPMPO-OOH appeared very similar to that 
of DEPMPO-OOH when we studied the effect of cell fractions ${ }^{[21]}$. The only significant difference concerned the interaction with P450 Fe(III)-heme but we showed here (using SKF $525 \mathrm{~A}$ ) that it was not the main metabolic pathway in the cells. A determinant parameter seemed to be the extracellular localization of the spin trap (and thus of the spin adduct). This conclusion was supported by experiments using the spin probe $\mathrm{Ni}(\mathrm{en})_{3}{ }^{2+}$ (Fig. 8) and by literature observations that only slight amounts of permethylated $\beta$-cyclodextrin can enter phospholipids liposomes ${ }^{[54]}$. Assuming that CD-DIPPMPO does not enter cells, the small and cell number-independent increase in CD-DIPPMPO-OOH decay in our experiments could be due to the release of intracellular material from cells that have been damaged during the manipulation.

The superior ability of CD-DIPPMPO to detect superoxide produced by RAW macrophages would therefore rely on its protection against the main reduction mechanisms within the cell, involving thiols and ascorbate (Scheme 2). This observation of extracellular production of superoxide by PMA-stimulated RAW macrophages is contrary to the results obtained by Hurst et al. ${ }^{[55]}$, who concluded that the release of superoxide in the extracellular medium was negligible, based on measurements using hydroxylamine spin probes. Since their experiments were performed in a sealed flat cell, we suspect that the flux of superoxide was lower than under our conditions where the gas-permeable teflon capillary allowed dioxygen in the solution to be constantly replenished.

\section{Conclusion}

Although CD-DIPPMPO seems restricted to the detection of extracellular superoxide, it appears as a superior spin trap for superoxide detection with high dynamic range and is likely to compete in sensitivity with hydroxylamine spin probes, while being more specific and less liable to give misleading results. Further evaluation using other cell lines that produce lower levels of superoxide is required to confirm this observation.

\section{Acknowledgments}

The authors wish to thank Dr. J.-C. Drapier (CNRS UPR 2301, Gif-sur-Yvette, France) for the generous gift of RAW 264.7 macrophages. They are also deeply grateful to Dr. A. Rockenbauer (Institute of Molecular Pharmacology, Research Centre for Natural Sciences, Budapest, Hungary) for the use of his simulation program and for his precious advice regarding the simulation of the ESR spectra; to Drs. B. Tuccio and R. Lauricella (UMR AMUCNRS 7273, Marseille, France) for helpful discussions concerning the application of the SVD method to ESR data; to Dr. J.-L. Boucher for stimulating discussions during the course of this work and for his critical reading of the manuscript; and to Drs. Y.-M. Frapart and D. Mansuy for their scientific guidance at the beginning of this work.

The authors are indebted to CNRS and the Agence Nationale de la Recherche (ANR-09BLAN-0193-02, SPIN BioRad) for their financial support.

\section{Abbreviations}

BMPO, 5-tert-butoxycarbonyl-5-methyl-1-pyrroline $N$-oxide; CAT, catalase; CD-DIPPMPO, 6-monodeoxy-6-mono-4-[(5-diisopropoxyphosphoryl-5-methyl-1-pyrroline- $N$-oxyde)ethylenecarbamoyl-(2,3-di- $O$-methyl) hexakis $\quad(2,3,6$-tri- $O$-methyl)]- $\beta$-cyclodextrin; DEPMPO, 5-diethoxyphosphoryl-5-methyl-1-pyrroline $N$-oxide; $\quad$ DIPPMPO, 5diisopropoxyphosphoryl-5-methyl-1-pyrroline $N$-oxide; DMPO, 5,5-dimethyl-1-pyrroline $N$ - 
oxide; DOSY NMR, diffusion order spectroscopy nuclear magnetic resonance; DPI, diphenyliodonium chloride; DTPA, diethylene triamine pentaacetic acid; EMPO, 5ethoxycarbonyl-5-methyl-1-pyrroline $N$-oxide; ESI-HRMS, electrospray ionization-highresolution mass spectrometry; ESR, electron spin resonance (equivalent to EPR, electron paramagnetic resonance); Mito-DIPPMPO, (4R*,5R*)-5-(diisopropyloxyphosphoryl)-5methyl-4-[(\{[2-(triphenylphosphonio)ethyl]carbamoyl $\}$ oxy)methyl]pyrroline $\quad \mathrm{N}$-oxide bromide; NEM, $N$-ethylmaleimide; NOX2, NADPH oxidase 2; P450, cytochrome P450; PEG, polyethylene glycol; PKC, protein kinase C; PMA, phorbol 12-myristate 13-acetate; ROS, reactive oxygen species; SKF 525A, $N, N$-diethylaminoethyl 2,2-diphenylvalerate hydrochloride; SOD, superoxide dismutase; $t_{1 / 2}$, half lifetime; TEMPO, $(2,2,6,6-$ tetramethyl)piperidine-1-oxyl; TEMPOL， 4-hydroxy-2,2,6,6-tetramethylpiperidin-1-oxyl; TOMER, 2-diethoxyphosphoryl-2,5,5-trimethyl-pyrrolidin-1-oxyl; X, xanthine; XO, xanthine oxidase.

Appendix A. Supporting information.

\section{References}

[1] Valko, M.; Leibfritz, D.; Moncol, J.; Cronin, M. T. D.; Mazur, M.; Telser, J. Free radicals and antioxidants in normal physiological functions and human disease. Int. J. Biochem. Cell Biol. 39:44-84; 2007.

[2] Brieger, K.; Schiavone, S.; Miller, J.; Krause, K. Reactive oxygen species: from health to disease. Swiss Med. Wkly. 142:w13659; 2012.

[3] Li, X.; Fang, P.; Mai, J.; Choi, E. T.; Wang, H.; Yang, X. Targeting mitochondrial reactive oxygen species as novel therapy for inflammatory diseases and cancers. J. Hematol. Oncol.J Hematol Oncol 6:19; 2013.

[4] Kim, G. H.; Ryan, J. J.; Archer, S. L. The role of redox signaling in epigenetics and cardiovascular disease. Antioxid. Redox Signal. 18:1920-1936; 2013.

[5] Chaturvedi, R. K.; Flint Beal, M. Mitochondrial Diseases of the Brain. Free Radic. Biol. Med. 63:1-29; 2013.

[6] Janzen, E. Spin Trapping. Acc. Chem. Res. 4:31-40; 1971.

[7] Bartosz, G. Use of spectroscopic probes for detection of reactive oxygen species. Clin. Chim. Acta Int. J. Clin. Chem. 368:53-76; 2006.

[8] Harbour, J. R.; Bolton, J. R. Superoxide formation in spinach chloroplasts: electron spin resonance detection by spin trapping. Biochem. Biophys. Res. Commun. 64:803-807; 1975.

[9] Green, M. R.; Hill, H. A.; Okolow-Zubkowska, M. J.; Segal, A. W. The production of hydroxyl and superoxide radicals by stimulated human neutrophils - measurements by EPR spectroscopy. FEBS Lett. 100:23-26; 1979.

[10] Rosen, H.; Klebanoff, S. J. Hydroxyl radical generation by polymorphonuclear leukocytes measured by electron spin resonance spectroscopy. J. Clin. Invest. 64:1725-1729; 1979.

[11] Hume, D. A.; Gordon, S.; Thornalley, P. J.; Bannister, J. V. The production of oxygen- 
Free Radic Biol Med. 2014 Jun; 71: 281-90. doi: 10.1016/j.freeradbiomed.2014.03.019

centered radicals by bacillus-Calmette-Guerin-activated macrophages. An electron paramagnetic resonance study of the response to phorbol myristate acetate. Biochim. Biophys. Acta 763:245-250; 1983.

[12] Bannister, J. V.; Bannister, W. H. Production of oxygen-centered radicals by neutrophils and macrophages as studied by electron spin resonance (ESR). Environ. Health Perspect. 64:37-43; 1985.

[13] Samuni, A.; Samuni, A.; Swartz, H. M. The cellular-induced decay of DMPO spin adducts of .OH and .O2-. Free Radic. Biol. Med. 6:179-183; 1989.

[14] Frejaville, C.; Karoui, H.; Tuccio, B.; Lemoigne, F.; Culcasi, M.; Pietri, S.; Lauricella, R.; Tordo, P. 5-Diethoxyphosphoryl-5-methyl-1-pyrroline N-oxide (DEPMPO) - a new phosphorylated nitrone for the efficient in-vitro and in-vivo spin-trapping of oxygen-centered radicals. J. Chem. Soc.-Chem. Commun. 1793-1794; 1994.

[15] Chalier, F.; Tordo, P. 5-Diisopropoxyphosphoryl-5-methyl-1-pyrroline N-oxide, DIPPMPO, a crystalline analog of the nitrone DEPMPO: synthesis and spin trapping properties. J. Chem. Soc.-Perkin Trans. 2 2110-2117; 2002.

[16] Zhao, H. T.; Joseph, J.; Zhang, H.; Karoui, H.; Kalyanaraman, B. Synthesis and biochemical applications of a solid cyclic nitrone spin trap: A relatively superior trap for detecting superoxide anions and glutathiyl radicals. Free Radic. Biol. Med. 31:599-606; 2001.

[17] Olive, G.; Mercier, A.; Le Moigne, F.; Rockenbauer, A.; Tordo, P. 2-Ethoxycarbonyl-2methyl-3,4-dihydro-2H-pyrrole-1-oxide: evaluation of the spin trapping properties. Free Radic. Biol. Med. 28:403-408; 2000.

[18] Hardy, M.; Chalier, F.; Ouari, O.; Finet, J.-P.; Rockenbauer, A.; Kalyanaraman, B.; Tordo, P. Mito-DEPMPO synthesized from a novel NH2-reactive DEPMPO spin trap: a new and improved trap for the detection of superoxide. Chem. Commun. 1083-1085; 2007.

[19] Hardy, M.; Rockenbauer, A.; Vasquez-Vivar, J.; Felix, C.; Lopez, M.; Srinivasan, S.; Avadhani, N.; Tordo, P.; Kalyanaraman, B. Detection, characterization, and decay kinetics of ROS and thiyl adducts of Mito-DEPMPO spin trap. Chem. Res. Toxicol. 20:1053-1060; 2007.

[20] Hardy, M.; Bardelang, D.; Karoui, H.; Rockenbauer, A.; Finet, J.-P.; Jicsinszky, L.; Rosas, R.; Ouari, O.; Tordo, P. Improving the trapping of superoxide radical with a betacyclodextrin-5-diethoxyphosphoryl-5-methyl-1-pyrroline-N-oxide (DEPMPO) conjugate. Chem.- Eur. J. 15:11114-11118; 2009.

[21] Bézière, N.; Hardy, M.; Poulhès, F.; Karoui, H.; Tordo, P.; Ouari, O.; Frapart, Y.-M.; Rockenbauer, A.; Boucher, J.-L.; Mansuy, D.; Peyrot, F. Metabolic stability of superoxide adducts derived from newly developed cyclic nitrone spin traps. Free Radic. Biol. Med. 67:150-158; 2014.

[22] Bézière, N.; Frapart, Y.; Rockenbauer, A.; Boucher, J.-L.; Mansuy, D.; Peyrot, F. Metabolic stability of superoxide and hydroxyl radical adducts of a cyclic nitrone toward rat liver microsomes and cytosol: A stopped-flow ESR spectroscopy study. Free Radic. Biol. Med. 49:437-446; 2010. 
Free Radical Biology \& Medicine Accepted manuscript

Published in final edited form as:

Free Radic Biol Med. 2014 Jun; 71: 281-90. doi: 10.1016/j.freeradbiomed.2014.03.019

[23] Forman, H. J.; Torres, M. Reactive oxygen species and cell signaling: respiratory burst in macrophage signaling. Am. J. Respir. Crit. Care Med. 166:S4-8; 2002.

[24] Rosen, G. M.; Freeman, B. A. Detection of superoxide generated by endothelial cells. Proc. Natl. Acad. Sci. U. S. A. 81:7269-7273; 1984.

[25] Roubaud, V.; Sankarapandi, S.; Kuppusamy, P.; Tordo, P.; Zweier, J. L. Quantitative measurement of superoxide generation and oxygen consumption from leukocytes using electron paramagnetic resonance spectroscopy. Anal. Biochem. 257:210-217; 1998.

[26] Khramtsov, V.; Berliner, L. J.; Clanton, T. L. NMR spin trapping: Detection of free radical reactions using a phosphorus-containing nitrone spin trap. Magn. Reson. Med. 42:228-234; 1999.

[27] Dikalov, S. I.; Li, W.; Mehranpour, P.; Wang, S. S.; Zafari, A. M. Production of extracellular superoxide by human lymphoblast cell lines: comparison of electron spin resonance techniques and cytochrome $C$ reduction assay. Biochem. Pharmacol. 73:972-980; 2007.

[28] Saito, K.; Takahashi, M.; Kamibayashi, M.; Ozawa, T.; Kohno, M. Comparison of superoxide detection abilities of newly developed spin traps in the living cells. Free Radic. Res. 43:668-676; 2009.

[29] Mitchell, D. G.; Rosen, G. M.; Tseitlin, M.; Symmes, B.; Eaton, S. S.; Eaton, G. R. Use of rapid-scan EPR to improve detection sensitivity for spin-trapped radicals. Biophys. J. 105:338-342; 2013.

[30] Le Moigne, F.; Mercier, A.; Tordo, P. $\beta$-Phosphorylated cyclic nitroxides. 2. Synthesis of pyrrolidin- and piperidin-2-yl phosphonates and the corresponding stable nitroxides. Tetrahedron Lett. 32:3841-3844; 1991.

[31] Vanduijn, M. M.; Van der Zee, J.; Van den Broek, P. J. A. Analysis of transmembrane redox reactions: Interaction of intra- and extracellular ascorbate species. Methods Enzymol. 352:268-279; 2002.

[32] Zannoni, V.; Lynch, M.; Goldstein, S.; Sato, P. Rapid micromethod for determination of ascorbic acid in plasma and tissues. Biochem. Med. 11:41-48; 1974.

[33] Khan, N.; Wilmot, C. M.; Rosen, G. M.; Demidenko, E.; Sun, J.; Joseph, J.; O’Hara, J.; Kalyanaraman, B.; Swartz, H. M. Spin traps: in vitro toxicity and stability of radical adducts. Free Radic. Biol. Med. 34:1473-1481; 2003.

[34] Bainton, D. F. The cells of inflammation: a general view. In: Weissman, G., ed. Handbook of inflammation. Amsterdam: Elsevier/North-Holland Biomedical Press; 1980: 125 .

[35] Wakefield, L. M.; Cass, A. E.; Radda, G. K. Electron transfer across the chromaffin granule membrane. Use of EPR to demonstrate reduction of intravesicular ascorbate radical by the extravesicular mitochondrial NADH:ascorbate radical oxidoreductase. J. Biol. Chem. 261:9746-9752; 1986.

[36] Lauricella, R.; Allouch, A.; Roubaud, V.; Bouteiller, J.-C.; Tuccio, B. A new kinetic 
Free Radical Biology \& Medicine Accepted manuscript

Published in final edited form as:

Free Radic Biol Med. 2014 Jun; 71: 281-90. doi: 10.1016/j.freeradbiomed.2014.03.019

approach to the evaluation of rate constants for the spin trapping of superoxide/hydroperoxyl radical by nitrones in aqueous media. Org. Biomol. Chem. 2:1304-1309; 2004.

[37] Rockenbauer, A.; Korecz, L. Automatic computer simulations of ESR spectra. Appl. Magn. Reson. 10:29-43; 1996.

[38] Grzelak, A.; Rychlik, B.; Bartosz, G. Light-dependent generation of reactive oxygen species in cell culture media. Free Radic. Biol. Med. 30:1418-1425; 2001.

[39] Beckman, J. S.; Minor, R. L.; White, C. W.; Repine, J. E.; Rosen, G. M.; Freeman, B. A. Superoxide dismutase and catalase conjugated to polyethylene glycol increases endothelial enzyme activity and oxidant resistance. J. Biol. Chem. 263:6884-6892; 1988.

[40] Leinisch, F.; Ranguelova, K.; DeRose, E. F.; Jiang, J.; Mason, R. P. Evaluation of the Forrester-Hepburn mechanism as an artifact source in ESR spin-trapping. Chem. Res. Toxicol. 24:2217-2226; 2011.

[41] Perrier, E.; Fournet-Bourguignon, M.-P.; Royere, E.; Molez, S.; Reure, H.; Lesage, L.; Gosgnach, W.; Frapart, Y.; Boucher, J.-L.; Villeneuve, N.; Vilaine, J.-P. Effect of uncoupling endothelial nitric oxide synthase on calcium homeostasis in aged porcine endothelial cells. Cardiovasc. Res. 82:133-142; 2009.

[42] Liu, K. J.; Miyake, M.; Panz, T.; Swartz, H. Evaluation of DEPMPO as a spin trapping agent in biological systems. Free Radic. Biol. Med. 26:714-721; 1999.

[43] Culcasi, M.; Rockenbauer, A.; Mercier, A.; Clément, J.-L.; Pietri, S. The line asymmetry of electron spin resonance spectra as a tool to determine the cis:trans ratio for spin-trapping adducts of chiral pyrrolines N-oxides: the mechanism of formation of hydroxyl radical adducts of EMPO, DEPMPO, and DIPPMPO in the ischemic-reperfused rat liver. Free Radic. Biol. Med. 40:1524-1538; 2006.

[44] Ouari, O.; Hardy, M.; Karoui, H.; Tordo, P. Recent developments and applications of the coupled EPR/Spin trapping technique (EPR/ST). In: Gilbert, B. C.; Murphy, D. M.; Chechik, V., eds. Electron Paramagnetic Resonance, volume 22. Cambridge: RSC Publishing; 2011: 140 .

[45] Samuni, A.; Krishna, C. M.; Riesz, P.; Finkelstein, E.; Russo, A. Superoxide reaction with nitroxide spin-adducts. Free Radic. Biol. Med. 6:141-148; 1989.

[46] Bielski, B. H. J.; Cabelli, D. E.; Arudi, R. L.; Ross, A. B. Reactivity of HO2/O2Radicals in Aqueous Solution. J. Phys. Chem. Ref. Data 14:1041-1100; 1985.

[47] Berliner, L. J.; Khramtsov, V.; Fujii, H.; Clanton, T. L. Unique in vivo applications of spin traps. Free Radic. Biol. Med. 30:489-499; 2001.

[48] Rohr-Udilova, N.; Stolze, K.; Marian, B.; Nohl, H. Cytotoxicity of novel derivatives of the spin trap EMPO. Bioorg. Med. Chem. Lett. 16:541-546; 2006.

[49] Zhai, Z.; Gomez-Mejiba, S. E.; Ramirez, D. C. The nitrone spin trap 5,5-dimethyl-1pyrroline N-oxide affects stress response and fate of lipopolysaccharide-primed RAW 264.7 macrophage cells. Inflammation 36:346-354; 2013. 
Free Radical Biology \& Medicine Accepted manuscript

Published in final edited form as:

Free Radic Biol Med. 2014 Jun; 71: 281-90. doi: 10.1016/j.freeradbiomed.2014.03.019

[50] Janzen, E. G.; Poyer, J. L.; Schaefer, C. F.; Downs, P. E.; DuBose, C. M. Biological spin trapping. II. Toxicity of nitrone spin traps: dose-ranging in the rat. J. Biochem. Biophys. Methods 30:239-247; 1995.

[51] Anderson, T. G.; Tan, A.; Ganz, P.; Seelig, J. Calorimetric measurement of phospholipid interaction with methyl-beta-cyclodextrin. Biochemistry 43:2251-2261; 2004.

[52] Pou, S.; Cohen, M. S.; Britigan, B. E.; Rosen, G. M. Spin-trapping and human neutrophils. Limits of detection of hydroxyl radical. J. Biol. Chem. 264:12299-12302; 1989.

[53] Anzai, K.; Aikawa, T.; Furukawa, Y.; Matsushima, Y.; Urano, S.; Ozawa, T. ESR measurement of rapid penetration of DMPO and DEPMPO spin traps through lipid bilayer membranes. Arch. Biochem. Biophys. 415:251-256; 2003.

[54] Nishijo, J.; Mizuno, H. Interactions of cyclodextrins with DPPC liposomes. Differential scanning calorimetry studies. Chem. Pharm. Bull. (Tokyo) 46:120-124; 1998.

[55] Palazzolo-Ballance, A. M.; Suquet, C.; Hurst, J. K. Pathways for intracellular generation of oxidants and tyrosine nitration by a macrophage cell line. Biochemistry 46:7536-7548; 2007. 
Free Radical Biology \& Medicine Accepted manuscript

Published in final edited form as:

Free Radic Biol Med. 2014 Jun; 71: 281-90. doi: 10.1016/j.freeradbiomed.2014.03.019

\section{Legends for figures and schemes}

Figure 1: Accumulation of the superoxide spin adduct of various cyclic nitrones in the presence of the X/XO system. DMPO $(10 \mathrm{mM})$, BMPO $(10 \mathrm{mM})$, DEPMPO $(10 \mathrm{mM})$, DIPPMPO (10 mM), Mito-DIPPMPO $(10 \mathrm{mM})$, or CD-DIPPMPO $(5 \mathrm{mM})$ was incubated at $21^{\circ} \mathrm{C}$ with $250 \mu \mathrm{M} \mathrm{X}$ and $100 \mathrm{U} / \mathrm{mL}$ CAT in PBS, pH 7.4, containing $1 \mathrm{mM}$ DTPA. The amount of $\mathrm{XO}$, required to produce a constant flux of superoxide of $2.8 \pm 0.3 \mu \mathrm{M} \cdot \mathrm{min}^{-1}$, was added to initiate the reaction. The kinetic curves were derived from simulation of the ESR spectra as described in the Experimental procedures. The means of at least three experiments $\pm \mathrm{SD}$ are shown. For the sake of clarity, half error bars are plotted for BMPO, DEPMPO, and CD-DIPPMPO, while error bars (similar in magnitude to those of DEPMPO) have been omitted for DIPPMPO and Mito-DIPPMPO. Fitted regression lines are displayed for MitoDIPPMPO $\left(r^{2}>0.998\right)$ and CD-DIPPMPO $\left(r^{2}>0.999\right)$, respectively.

Figure 2: Comparison of representative ESR spectra obtained with each studied spin trap in the presence of RAW macrophages. DMPO $(10 \mathrm{mM})$, BMPO $(10 \mathrm{mM})$, DEPMPO (10 $\mathrm{mM})$, DIPPMPO (10 mM), Mito-DIPPMPO (10 mM), or CD-DIPPMPO $(5 \mathrm{mM})$ was incubated with RAW macrophages $\left(3.6 \pm 0.3 \times 10^{6}\right.$ cells $\left./ 100 \mu \mathrm{L}\right)$ in PBS $(\mathrm{pH} 7.1-7.4)$ and $1 \mathrm{mM}$ DTPA, in the absence or presence of PEG-SOD $(200 \mathrm{U} / \mathrm{mL})$. When indicated, the macrophages were either not treated (NT) or activated by PMA $(5 \mu \mathrm{M}, 20 \mathrm{~min})$ prior to the incubation with the spin trap. ESR settings are described under the Experimental procedures. The sums of 5 scans obtained after 8 min incubation are presented, except for DMPO and BMPO, for which the sum of the five initial spectra are shown. Representative spectra of at least three independent experiments are shown.

Figure 3: Concentrations of superoxide and hydroxyl radical adducts of the studied spin traps obtained with PMA-stimulated RAW macrophages, in the presence or absence of SOD-PEG. DMPO (10 mM), BMPO (10 mM), DEPMPO (10 mM), DIPPMPO (10 mM), Mito-DIPPMPO $(10 \mathrm{mM})$, or CD-DIPPMPO $(5 \mathrm{mM})$ was incubated with RAW macrophages (3.6 $\pm 0.3 \times 10^{6}$ cells $\left./ 100 \mu \mathrm{L}\right)$ in PBS (pH 7.1-7.4) and $1 \mathrm{mM}$ DTPA, in the absence (upper panel) or presence (lower panel) of PEG-SOD $(200 \mathrm{U} / \mathrm{mL})$. The macrophages were activated by PMA $(5 \mu \mathrm{M}, 20 \mathrm{~min})$ prior to the incubation with the spin trap. The concentration of each adduct was derived from computer simulation of the ESR spectra in Fig. 1 as described under Experimental procedures. The data are the average of at least three independent experiments and the error bars reflect the standard deviation.

Figure 4: Representative evolution with time of the spin adducts obtained with DEPMPO, DIPPMPO, Mito-DIPPMPO, and CD-DIPPMPO in the presence of PMAstimulated RAW macrophages. Detection of superoxide adducts (A) and of hydroxyl radical adducts (B). DEPMPO (10 mM), DIPPMPO (10 mM), Mito-DIPPMPO (10 mM), or CDDIPPMPO $(5 \mathrm{mM})$ was incubated with RAW macrophages $\left(3.6 \pm 0.3 \times 10^{6}\right.$ cells $\left./ 100 \mu \mathrm{L}\right)$ in PBS (pH 7.1-7.4) and $1 \mathrm{mM}$ DTPA. The macrophages were activated by PMA $(5 \mu \mathrm{M}, 20 \mathrm{~min})$ prior to the incubation with the spin trap. The concentration of each adduct was derived from computer simulation of the ESR spectra as described under Experimental procedures. The kinetic curves are representative of at least three independent experiments.

Figure 5: Comparison of the representative ESR spectra obtained with DEPMPO or CD-DIPPMPO in the presence of non stimulated macrophages after noise filtering. DEPMPO $(10 \mathrm{mM})$ or CD-DIPPMPO $(5 \mathrm{mM})$ was incubated for 8 min with non stimulated RAW macrophages $\left(3.6 \pm 0.3 \times 10^{6}\right.$ cells $\left./ 100 \mu \mathrm{L}\right)$ in PBS ( $\mathrm{pH}$ 7.1-7.4) and $1 \mathrm{mM}$ DTPA. ESR 
settings are described under the Experimental procedures. Noise in the sum of 5 spectra was filtered using the SVD procedure described by Lauricella et al. ${ }^{[36]}$ The y-axis scale was expanded 5-fold compared to the unsmoothed spectra shown in Fig. 2. (See also Supplementary Fig. S2 for further details).

Figure 6: Influence of RAW macrophages on the stability of DEPMPO-OOH (A) and on its conversion to DEPMPO-OH (B). DEPMPO-OOH was pre-formed by incubation of DEPMPO $(10 \mathrm{mM})$ with $\mathrm{X}(250 \mu \mathrm{M})$, CAT $(100 \mathrm{U} / \mathrm{mL})$, DTPA $(1 \mathrm{mM})$, and XO $(8 \mathrm{mU} / \mathrm{mL})$

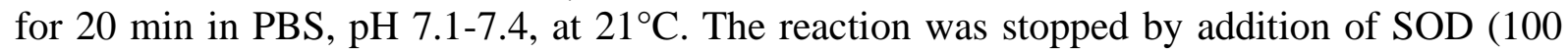
$\mathrm{U} / \mathrm{mL}$ ). Recording of the ESR spectra as a function of time was started immediately after mixing with RAW macrophages $\left(3.6 \pm 0.3 \times 10^{6}\right.$ cells for $\left.100 \mu \mathrm{L}\right)$ or an equivalent buffer volume. When indicated, $300 \mu \mathrm{M}$ NEM, a thiol blocking reagent, were added to the incubation. The concentration of each adduct was derived from computer simulation of the ESR spectra as described under Experimental procedures. The kinetic curves are representative of at least three independent experiments.

Figure 7: Influence of RAW macrophages on the stability of CD-DIPPMPO-OOH (A) and on its conversion to CD-DIPPMPO-OH (B). CD-DIPPMPO-OOH was pre-formed by incubation of CD-DIPPMPO $(5 \mathrm{mM})$ with X $(250 \mu \mathrm{M})$, CAT $(100 \mathrm{U} / \mathrm{mL})$, DTPA $(1 \mathrm{mM})$, and $\mathrm{XO}(8 \mathrm{mU} / \mathrm{mL})$ for $20 \mathrm{~min}$ in $\mathrm{PBS}, \mathrm{pH} 7.1-7.4$, at $21^{\circ} \mathrm{C}$. The reaction was stopped by addition of SOD $(100 \mathrm{U} / \mathrm{mL})$. Recording of the ESR spectra as a function of time was started immediately after mixing with RAW macrophages $\left(3.6 \pm 0.3 \times 10^{6}\right.$ cells for $\left.100 \mu \mathrm{L}\right)$ or an equivalent buffer volume. The concentration of each adduct was derived from computer simulation of the ESR spectra as described under Experimental procedures. The kinetic curves are representative of at least three independent experiments.

Figure 8: Effect of $\mathrm{Ni}(\mathrm{en}) 3^{2+}$, a cell impermeable paramagnetic agent, on the ESR signal of CD-DIPPMPO-OOH produced by incubation with the $\mathrm{X} / \mathrm{XO}$ system, in the absence or presence of RAW macrophages. CD-DIPPMPO-OOH was pre-formed by incubation of CD-DIPPMPO $(5 \mathrm{mM})$ with $\mathrm{X}(250 \mu \mathrm{M})$, CAT $(100 \mathrm{U} / \mathrm{mL})$, DTPA $(1 \mathrm{mM})$, and XO (8 $\mathrm{mU} / \mathrm{mL}$ ) for $20 \mathrm{~min}$ in $\mathrm{PBS}, \mathrm{pH} 7.1-7.4$, at $21^{\circ} \mathrm{C}$. The reaction was stopped by addition of SOD $(100 \mathrm{U} / \mathrm{mL})$. When indicated, $\mathrm{Ni}(\mathrm{en}) 3^{2+}(100 \mathrm{mM})$ was added and the ESR recording was started immediately. The same experiment was repeated in the presence of RAW macrophages $\left(3.6 \pm 0.3 \times 10^{6}\right.$ cells for $\left.100 \mu \mathrm{L}\right)$. Sums of 5 scans are presented.

Scheme 1: Structure of the spin traps under study and general structures for superoxide and hydroxyl adducts.

Scheme 2: Mechanism of superoxide production by PMA-stimulated RAW macrophages and of the formation and decay of superoxide adducts of two representative cyclic nitrone spin traps, DEPMPO and CD-DIPPMPO. Specific abbreviations used in the scheme : Asc, ascorbic acid; NOX2, NADPH oxidase 2; GSH/GPx, glutathione/glutathione peroxidase; $\mathrm{PKC}$, protein kinase $\mathrm{C}$. 
Free Radical Biology \& Medicine Accepted manuscript

Published in final edited form as:

Free Radic Biol Med. 2014 Jun; 71: 281-90. doi: 10.1016/j.freeradbiomed.2014.03.019

\section{Figures}

\section{Figure 1:}

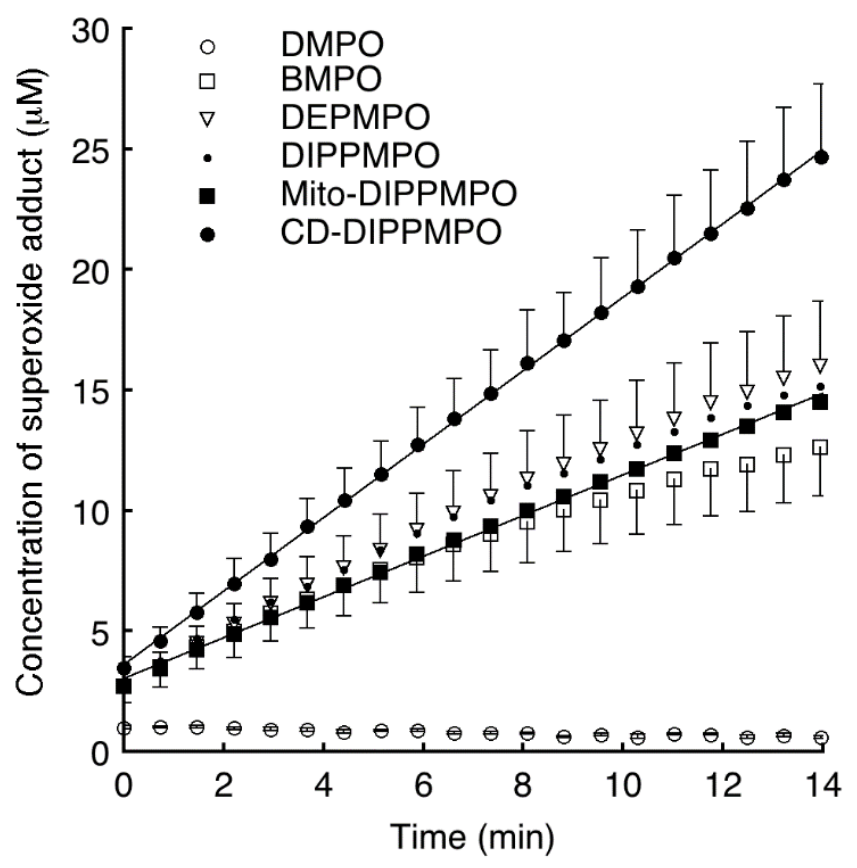

Figure 2:
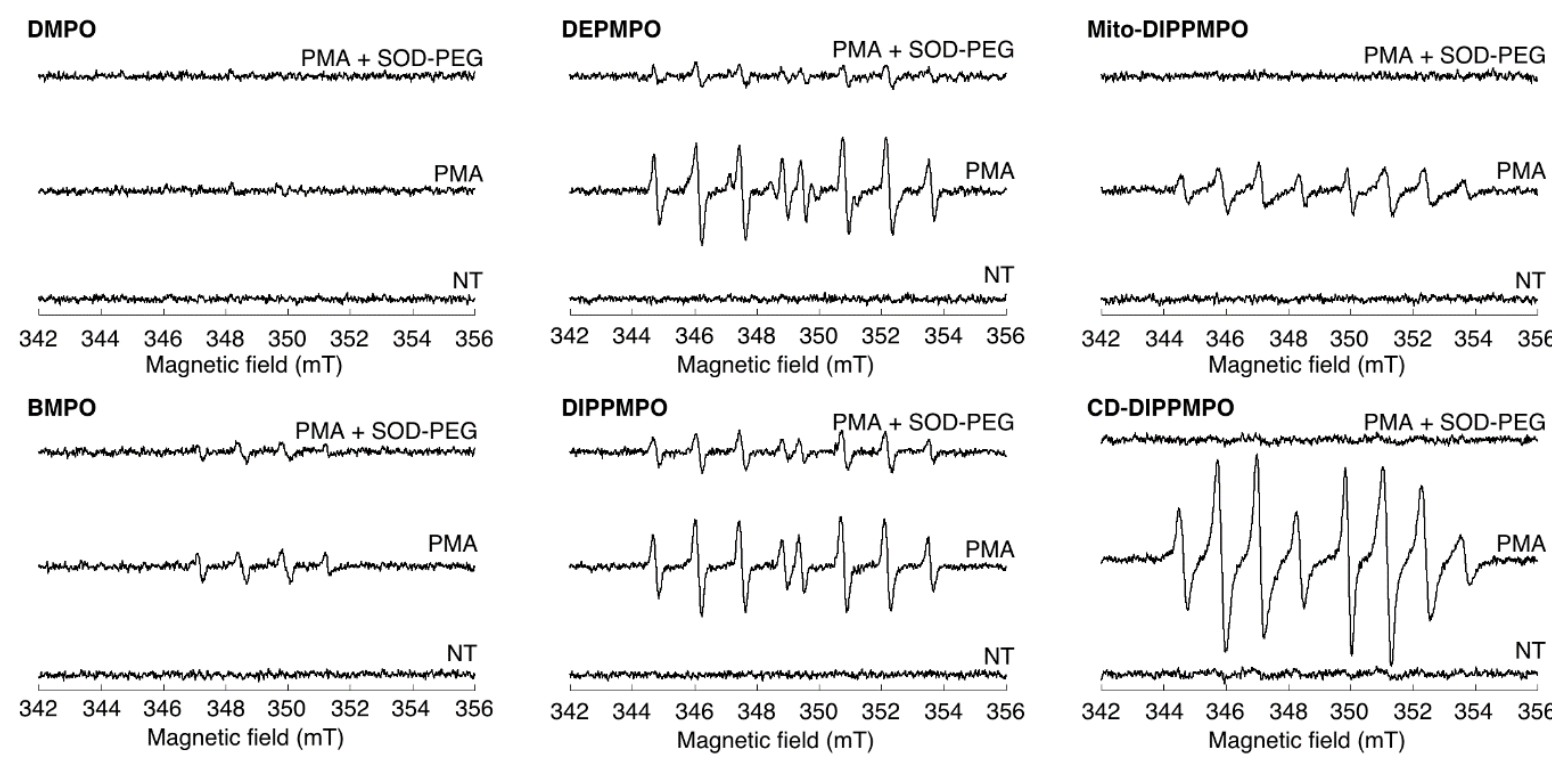

DIPPMPO
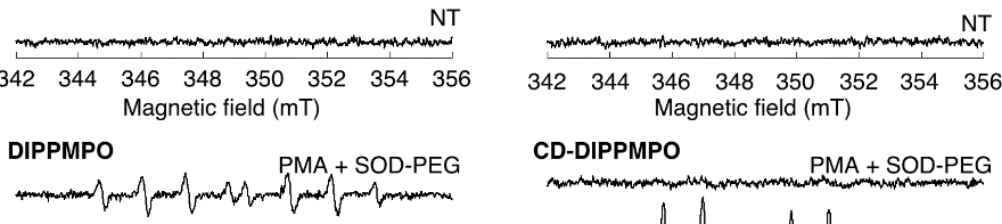

CD-DIPPMPO

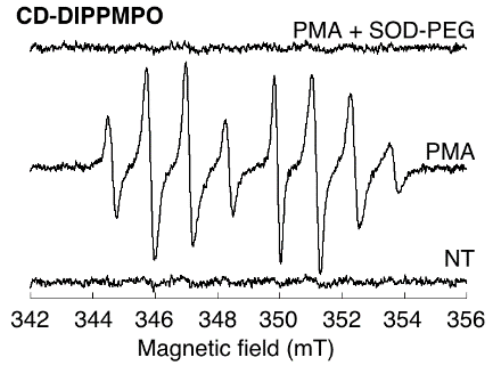


Free Radical Biology \& Medicine Accepted manuscript

Published in final edited form as:

Free Radic Biol Med. 2014 Jun; 71: 281-90. doi: 10.1016/j.freeradbiomed.2014.03.019

\section{Figure 3:}

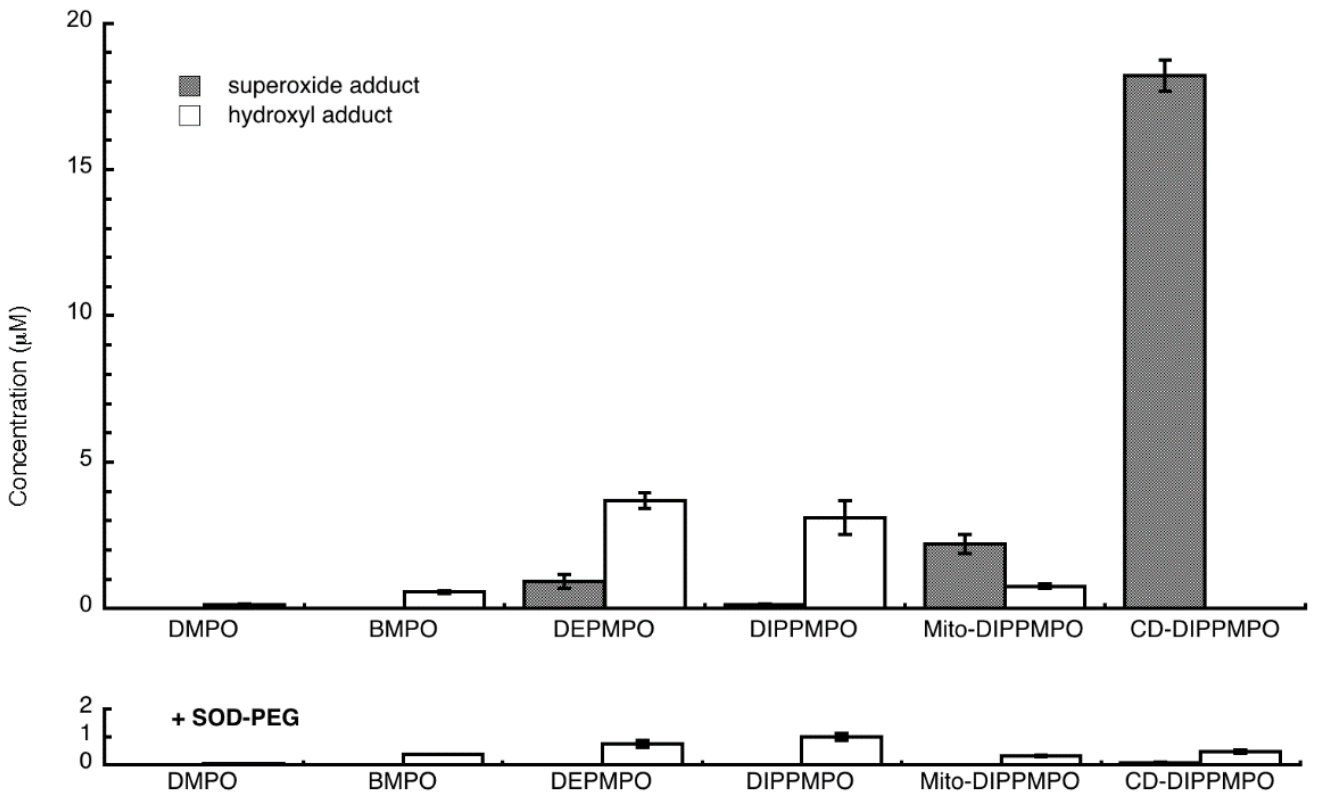


Free Radical Biology \& Medicine Accepted manuscript

Published in final edited form as:

Free Radic Biol Med. 2014 Jun; 71: 281-90. doi: 10.1016/j.freeradbiomed.2014.03.019

Figure 4:

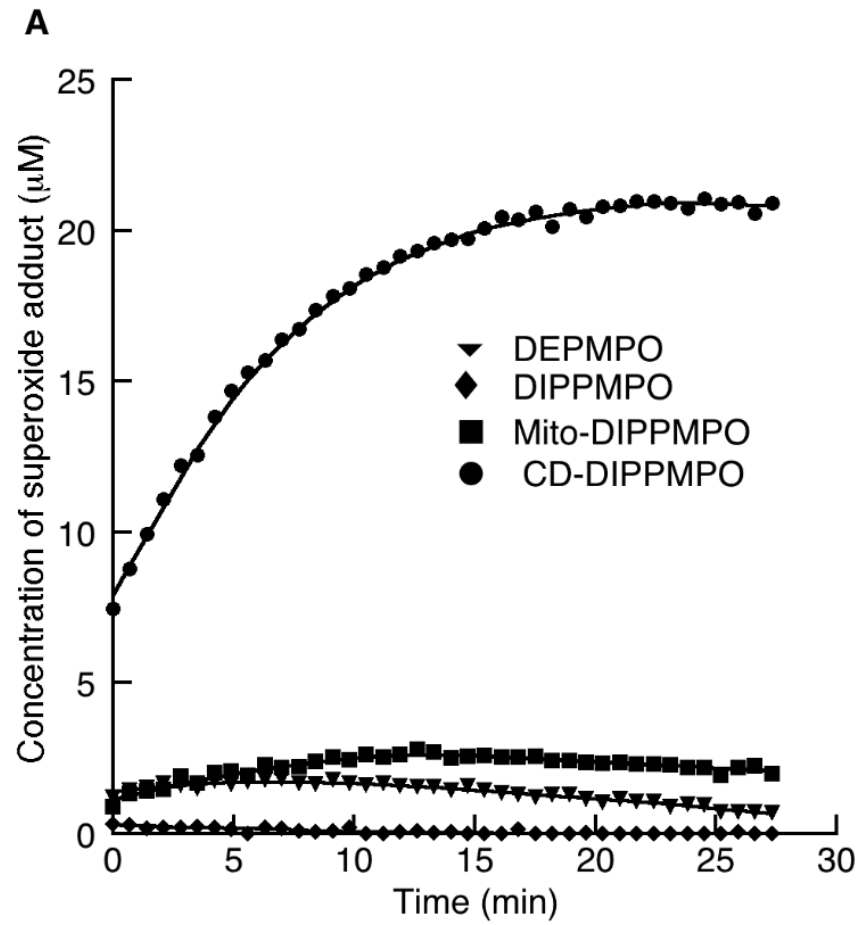

B

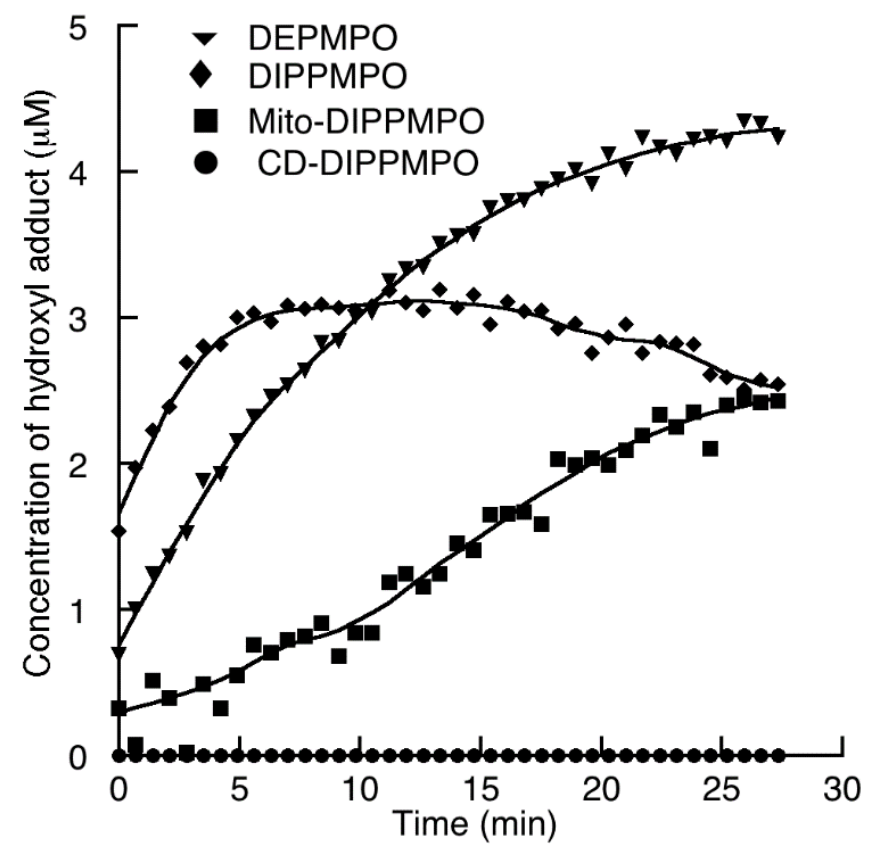


Free Radical Biology \& Medicine Accepted manuscript

Published in final edited form as:

Free Radic Biol Med. 2014 Jun; 71: 281-90. doi: 10.1016/j.freeradbiomed.2014.03.019

\section{Figure 5:}
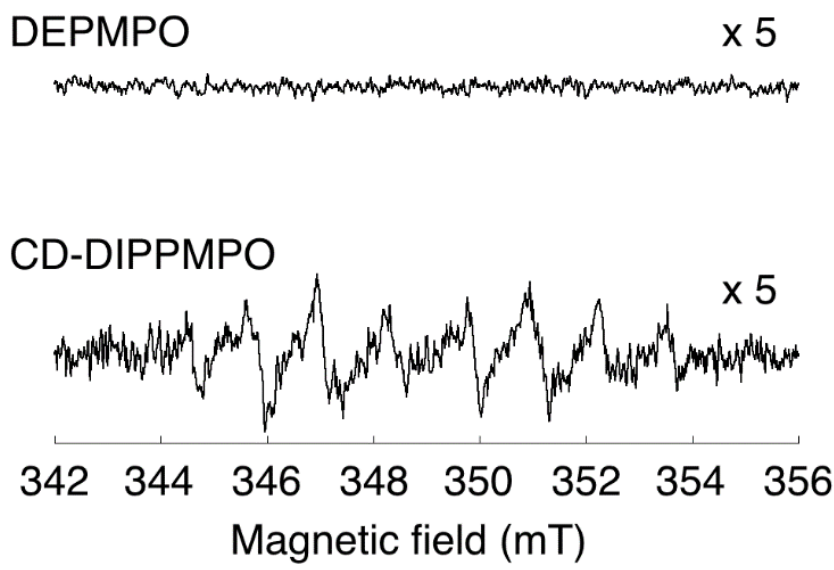
Free Radical Biology \& Medicine Accepted manuscript

Published in final edited form as:

Free Radic Biol Med. 2014 Jun; 71: 281-90. doi: 10.1016/j.freeradbiomed.2014.03.019

Figure 6:
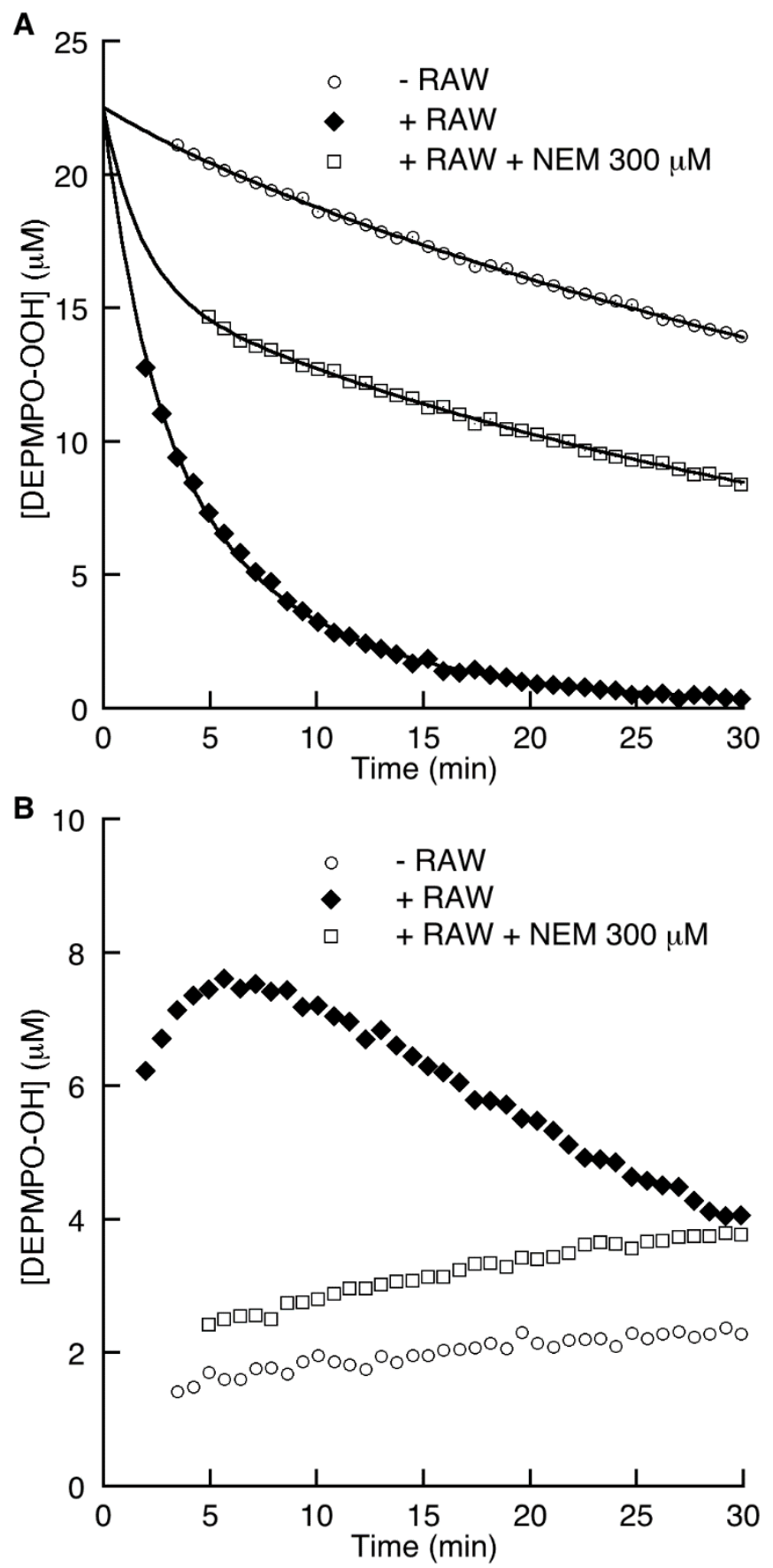
Free Radical Biology \& Medicine Accepted manuscript

Published in final edited form as:

Free Radic Biol Med. 2014 Jun; 71: 281-90. doi: 10.1016/j.freeradbiomed.2014.03.019

\section{Figure 7:}
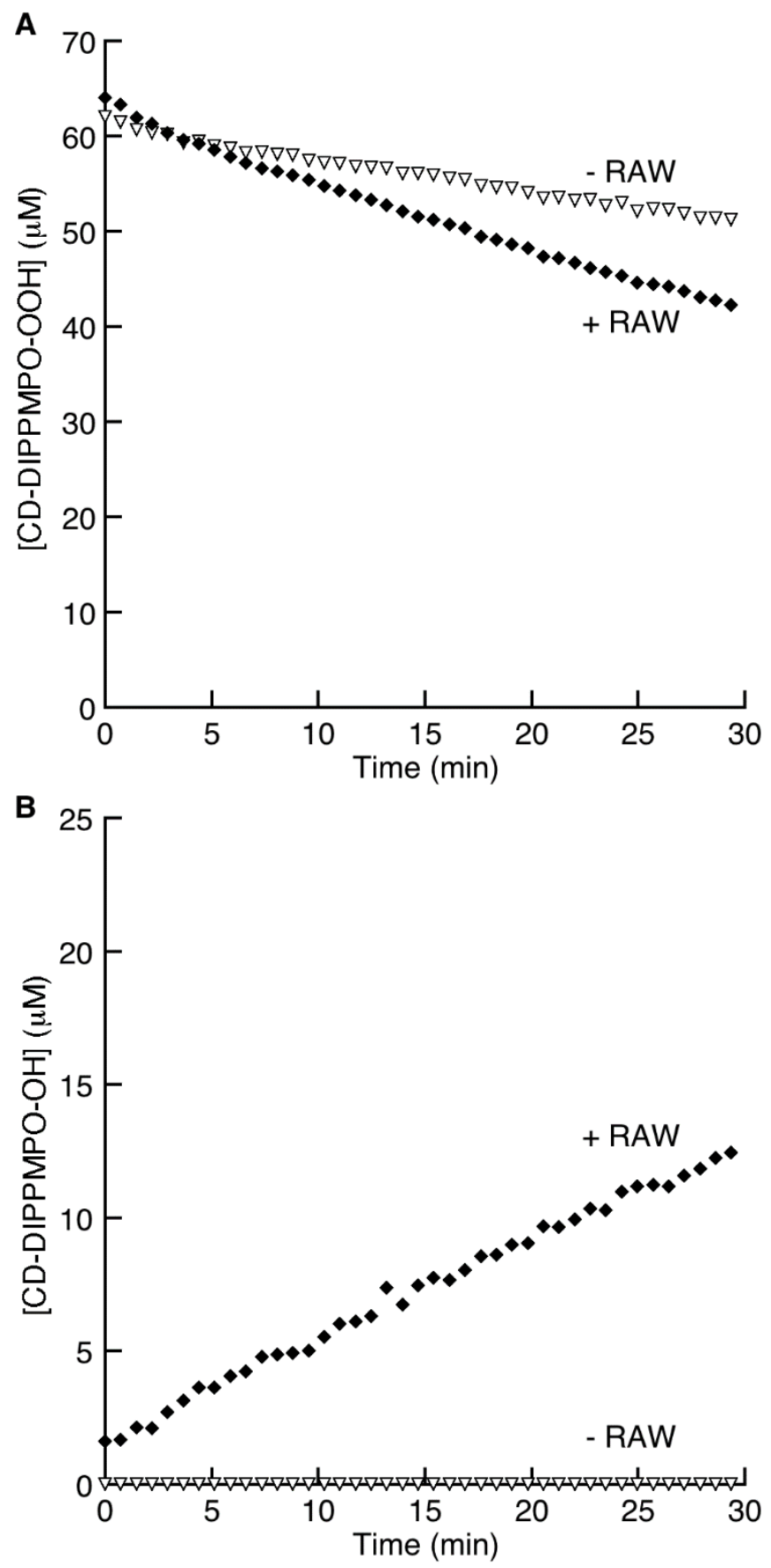
Free Radical Biology \& Medicine Accepted manuscript

Published in final edited form as:

Free Radic Biol Med. 2014 Jun; 71: 281-90. doi: 10.1016/j.freeradbiomed.2014.03.019

\section{Figure 8:}

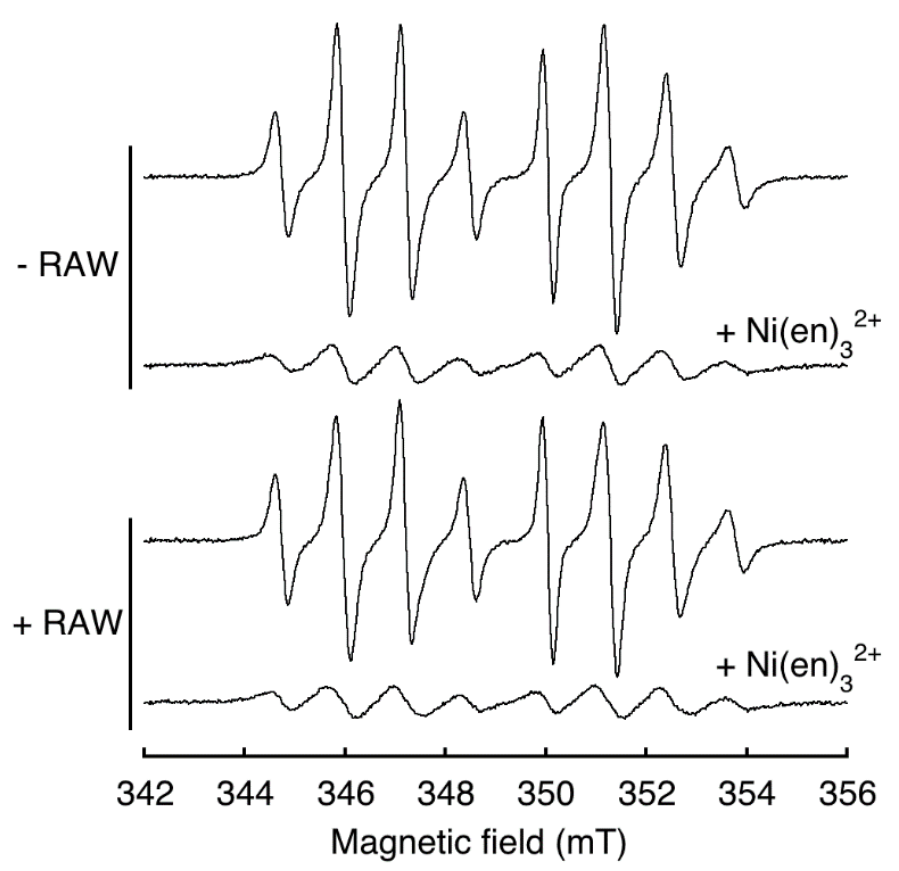

\section{Schemes}

\section{Scheme 1}<smiles>[X]C1(C)CCC=[N+]1[O-]</smiles>

DMPO: BMPO: DEPMPO: $\mathrm{X}=\mathrm{CO}_{2} \mathrm{C}\left(\mathrm{CH}_{3}\right)_{3}$ $\mathrm{X}=\mathrm{P}(\mathrm{O})\left(\mathrm{OC}_{2} \mathrm{H}_{5}\right)_{2}$ $\mathrm{X}=\mathrm{P}(\mathrm{O})\left(\mathrm{OCH}\left(\mathrm{CH}_{3}\right)_{2}\right)_{2}$

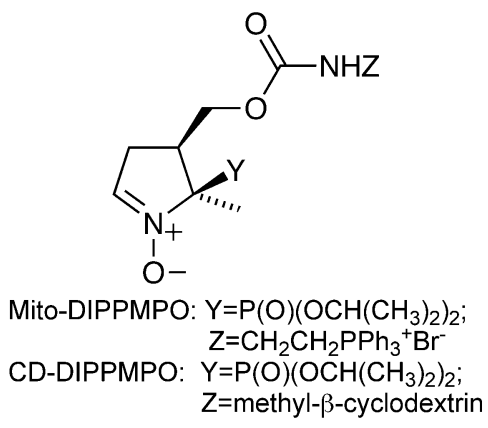


Free Radical Biology \& Medicine Accepted manuscript

Published in final edited form as:

Free Radic Biol Med. 2014 Jun; 71: 281-90. doi: 10.1016/j.freeradbiomed.2014.03.019

Scheme 2

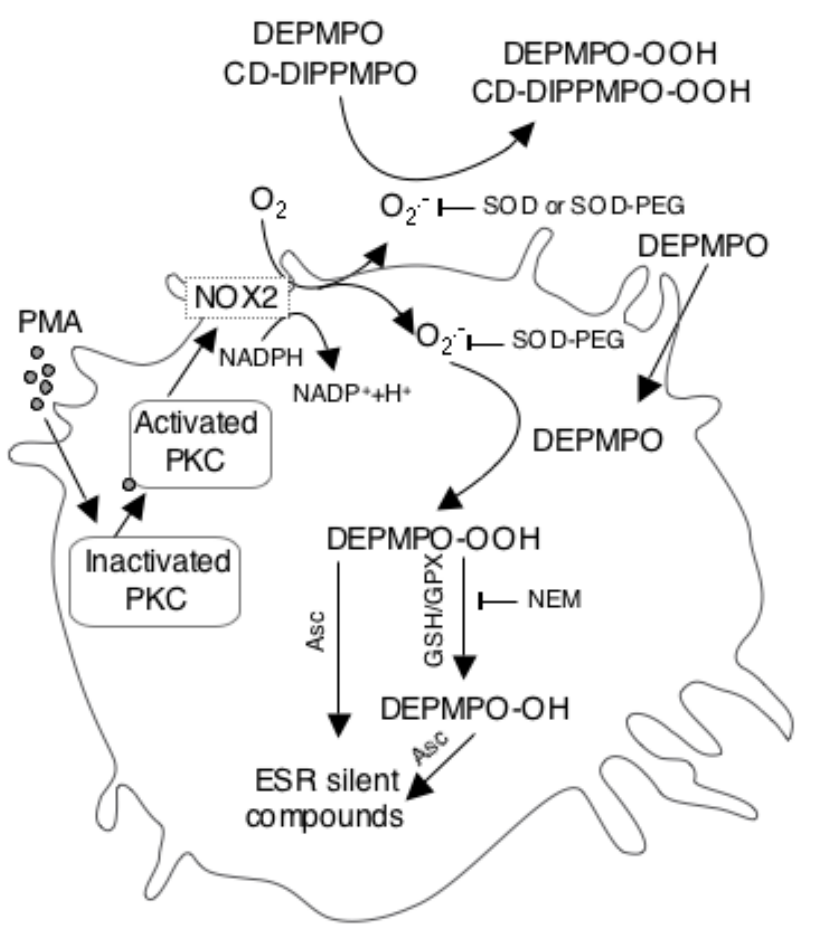

